\title{
Eight new species of Macvicaria Gibson and Bray, 1982 (Digenea: Opecoelidae) mainly from endemic temperate marine fishes of Australia
}

\author{
Thelma O. Aken’Ova ${ }^{1,2, \dagger}$, Thomas H. Cribb ${ }^{1, \ddagger} \&$ Rodney A. Bray ${ }^{3, \S}$
}

I Department of Microbiology and Parasitology, The University of Queensland, Brisbane, Australia 2 Department of Biological Sciences, Ahmadu Bello University, Zaria, Kaduna State, Nigeria 3 Department of Zoology, Natural History Museum, London, UK

† urn:lsid:zoobank.org:author:1E914443-9180-46FC-AB66-1B5C11AF5152

† urn:lsid:zoobank.org:author:325DB589-56F9-4F65-A456-A0AA4A0A39FD

§ urn:lsid:zoobank.org:author:C053AFDE-D221-4BE1-9B0A-30307A67D4CO

Corresponding author: RodneyA. Bray (rab@nhm.ac.uk)

Academic editor: David Gibson | Received 9 June 2008 | Accepted 23 June 2008 | Published 10 July 2008

urn:lsid:zoobank.org:pub:66595057-9C2C-4AEF-AD29-9E2F52BF99FD

Citation: Aken'Ova TO, Cribb TH, Bray RA (2008) Eight new species of Macvicaria Gibson and Bray, 1982 (Digenea: Opecoelidae) mainly from endemic temperate marine fishes of Australia. ZooKeys 1: 23-58. doi: 10.3897/zookeys.1.8

\begin{abstract}
Nine morphologically distinct species of Macvicaria Gibson \& Bray, 1982 were recovered from six families, ten genera and twelve species of marine fishes in the waters off the coast of Queensland, Western Australia and South Australia: M. shotteri n. sp. in Apogon fasciatus (type-host), Sillaginodes punctatus and Sillago bassensis from Moreton Bay (type-locality), off southern Western Australia and off Kangaroo Island, South Australia; M. mekistomorphe n. sp. in Sillago maculata from Moreton Bay; M. mutovitellina n. sp. in Dactylophora nigricans from off southern Western Australia; M. flexuomeatus n. sp. in Goniistius gibbosus (type-host) and Cheilodactylus rubrolabiatus from southern Western Australia; M. vitellocopiosa n. sp. in Sillaginodes punctatus from off Kangaroo Island, South Australia; M. dextrocaula n. sp. in Notolabrus parilus (type-host) and N. fucicola (Richardson) (Labridae) from off southern Western Australia (type-locality) and Kangaroo Island, South Australia; M. heronensis Bray \& Cribb, 1989 in Trachinotus coppingeri off Stradbroke Island, Queensland; M. adomeae n. sp. in Sillaginodes punctatus off Kangaroo Island, South Australia; M. kingscotensis n. sp. in Neoodax balteatus (type-host) and Haletta semifasciata off Kangaroo Island, South Australia. We have used the following characters to distinguish between the species of Macvicaria: general body form; length/width ratio; size of cirrussac; length of forebody; post-testicular extent of caeca; egg size; and the position of the genital pore. Most of the species of Macvicaria showed interspecific differences in all of the characters enumerated, the most dramatic being in the position of the genital pore in one species. All 11 specimens recovered from 2 species of Notolabrus were found to have a dextral genital pore. This is the second report of
\end{abstract}


amphitypy in the Opecoelidae. All of the host species, apart from Apogon fasciatus, are endemic to Australian or Australian and New Zealand waters. New combinations formed are: M. dactylopagri (Manter, 1954); M. deeghaensis (Gupta \& Gupta, 1988); M. eleuthoronemae (Wang, Wang \& Zhang, 1992); M. gerridis (Fischthal \& Thomas 1970); M. hunghuaensis (Qiu \& Li in Shen \& Qiu, 1995); M. longicirrata (Manter, 1963); M. oligolecithosus (Wang, Wang \& Zhang, 1992); M. synagris (Yamaguti, 1952).

\section{Keywords}

Digenea, Opecoelidae, Macvicaria, southern Australia, fishes, endemicity.

\section{Introduction}

Macvicaria Gibson \& Bray, 1982 is a large genus of marine opecoelids that are widely distributed around the world. The genus was erected by Gibson \& Bray (1982) for marine species of Plagioporus Stafford, 1904 (sensu lato), with a ventro-lateral genital pore and an excretory vesicle reaching at least to the level of the anterior testis. The other main diagnostic features of Macvicaria are an unlobed ovary, relatively large eggs and fields of vitelline follicles that extend into the forebody and are confluent dorsally and ventrally in post-testicular area and usually dorsally in the forebody. Three species of Macvicaria, M. macassarensis (Yamaguti, 1958), M. heronensis Bray \& Cribb, 1989 and $M$. dampieri Bray, 1990 have been reported from Australian waters by Bray \& Cribb (1989) and Bray (1990). Of the three species reported, M. dampieri is the only species from temperate waters. It is clear that Australian waters harbour many species, and the exploration of these worms is carried further in this study where nine species are reported, eight new. Cribb (2005) recognized this genus in his key to the Opecoelidae, based on the characters mentioned here. It has become a large genus, with many described species and with many species awaiting description.

This paper reports on the finding of eight new species of Macvicaria, almost all records are from endemic perciform hosts in waters off southern Queensland, southern Western Australia and South Australia. One known species is reported from southern Queensland for the first time.

\section{Materials and methods}

Opecoelids were collected live from fish as soon as they had died or been anaesthetized. The worms were washed in cold saline then fixed in hot saline and preserved in $5 \%$ formalin. Later, they were stained in Mayer's acid haematoxylin, dehydrated in a graded series of ethanol, cleared in methyl salicylate and mounted in Canada balsam. Measurements were taken using a digitizer and recorded in micrometres as ranges followed by their means in parentheses. Figures were prepared with the aid of a drawing tube on an Olympus BH2 microscope. Abbreviations: QM, Queensland Museum, Brisbane, Australia: http://www.qm.qld.gov.au/; BMNH, Natural History Museum, London, UK http://www.nhm.ac.uk/ 


\section{Results}

\section{Family Opecoelidae Ozaki, 1925}

\section{Subfamily Plagioporinae Manter, 1947}

\section{Genus Macvicaria Gibson \& Bray, 1982}

urn:Isid:zoobank.org:act:1B181DB5-4D60-4744-9520-730FD9B6AAB0

(syn. Cryptacetabulum Shalaby \& Hassanine, 1997)

Species of Macvicaria have been separated into five morphological groups, A to E, based on the distribution of vitelline follicles, the size of the cirrus-sac and the arrangement of the testes. It should be pointed out that it is difficult to assign some species to a particular group, so considerable care should be taken when using these groups. A sixth group, $\mathrm{F}$, comprises worms of unresolved status. All new combinations were originally in Plagioporus.

Group $A$. Species with lateral vitelline fields continuous in the ventral sucker area, oblique to tandem testes and cirrus-sac not normally extending posterior to the ventral sucker: Macvicaria alacris (Looss, 1901) Gibson \& Bray, 1982; M. soleae (Nicoll, 1910) Gibson \& Bray, 1982; M. microtestis Zdzitowiecki \& Cielecka, 1997; M. oligolecithosus (Wang, Wang \& Zhang, 1992) n. comb.

Comment: Nicoll (1910) figured and described M. alacris and M. soleae as having oblique testes; Gibson \& Bray (1982) figured them with tandem testes.

Group B. Species with lateral vitelline fields continuous in the ventral sucker area, tandem testes and a cirrus-sac usually not extending posterior to the ventral sucker: Macvicaria aegyptensis (Shalaby \& Hassanine, 1997) Cribb, 2005; M. crassigula (Linton, 1910) Bartoli, Bray \& Gibson, 1989; M. cynoglossi (Madhavi, 1975) Bray, 1990; M. chrysophrys (Nagaty \& Abdel Aal, 1969) Bray, 1985 (syn: Plagioporus saoudi Ramadan, 1985); M. dactylopagri (Manter, 1954) n. comb.; M. dubia (Stossich, 1905) Bartoli, Bray \& Gibson, 1989; M. eleuthoronemae (Wang, Wang \& Zhang, 1992) n. comb.; M. longicauda (Hafeezullah, 1971) Bijukumar, 1997; M. maillardi Bartoli, Bray \& Gibson, 1989; M. mormyri (Stossich, 1885) Bartoli, Gibson \& Bray, 1993; M. obovata (Molin, 1859) Bartoli, Bray \& Gibson, 1989; M. ophthalmolyci Zdzitowiecki, 1990; M. sillagonis (Yamaguti, 1938) Bray, 1985; M. taksengi Bray, 1985; M. hunghuaensis (Qiu \& $\mathrm{Li}$ in Shen \& Qiu, 1995) n. comb.

Comments: $M$. cynoglossi has obliquely tandem to tandem testes and can be accommodated in either Group A or B.

Although the cirrus-sac in M. ophthalmolyci extends posterior to the ventral sucker, we have not placed it in Group C because its cirrus-sac does not extend appreciably beyond the posterior margin of this sucker, as in the worms in the Group C, and because its general body form is different from the worms in Group C.

Macvicaria cynoglossi, $M$. ophthalmolyci, and $M$. dactylopagri can be distinguished from all the other worms in Group B as follows: M. cynoglossi has lobed testes, M. ophthalmolyci has the shortest forebody and the largest ventral sucker, and $M$. dactylopa- 
gri has the smallest post-testicular space, the largest oral sucker relative to the ventral sucker, and a genital pore which is closest to the anterior end.

Group C. Species with continuous lateral vitelline fields in the ventral sucker area, tandem to oblique or oblique testes and a cirrus-sac extending posterior to the ventral sucker: Macvicaria jagannathi (Gupta \& Singh, 1985) Bijukumar, 1997; M. longibursata Zdzitowiecki \& Cielecka, 1997; M. longisaccus (Fischthal \& Kuntz, 1964) Bray, 1985; M. deeghaensis (Gupta \& Gupta, 1988) n. comb.; M. gerridis (Fischthal \& Thomas 1970) n. comb.; M. longicirrata (Manter, 1963) n. comb.; M. skorai Zdzitowiecki, 1999; M. synagris (Yamaguti, 1952) n. comb.

Comments: Gibson \& Bray (1982) remarked on the close resemblance of Plagioporus gerridis Fischthal \& Thomas, 1972 to Pachycreadium Manter, 1954. This worm does not appear to conform to Manter's (1954) concept of the genus in relation to the position of the genital pore, which Manter said was median or sub-median, or with Manter's (1940) figure (as Plagioporus gastrocotylus) and Yamaguti's (1971) figure of the type-species Pachycreadium gastrocotylum Manter, 1940, which showed that the vitelline fields were separate in the forebody, dorsally and ventrally. The definition of Pachycreadium in Bartoli, Gibson \& Bray (1988) addressed these two points, among others, thereby excluding Plagioporus gerridis from Pachycreadium. In the light of this development, we propose the new combination M. gerridis for Plagioporus gerridis, which we have placed in Group C. The paratype of $P$. gerridis (USPC Coll. No. 70680) that we examined did not show the type of vitelline distribution figured and described by Fischthal \& Thomas (1972). In the paratype, the vitelline follicles do not extend into the forebody as they do normally in species of Macvicaria. However, it is possible that the figure of this species was drawn from the holotype and that the vitelline distribution we observed in the paratype is a variant of the type figured by Fischthal \& Thomas. The holotype was not available for study.

Bray (1985) remarked on the similarity of Plagioporus longicirratus Manter, 1963 to Gaevskayatrema spp. except in its having vitelline follicles which extended posterior to the testes. He suggested that $P$. longicirratus might be congeneric with $P$. synagris Yamaguti, 1952. We have compared the measurements and descriptions of the two worms and found them to be different. P. longicirratus is a more elongate worm with a width to length ratio of 1:3.64 versus 1:2.7 in P. synagris; it has a smaller ventral sucker with a sucker width ratio of $1: 1.18-1.2$ versus $1: 2.5$, a smaller pharynx, with a pharynx to oral sucker width ratio of $1: 1.7$ versus $1: 1.5$, a longer forebody of $41.5 \%$ versus $29.2 \%$ of body-length, a smaller post-testicular space $6.7 \%$ versus $16.7 \%$ of body-length, longer eggs 72-73 versus 57-66 and a more posteriorly located genital pore $27.4 \%$ versus $13.2 \%$ of body-length from anterior extremity in P. synagris. On the basis of our observations we conclude that these two worms are distinct. The vitelline follicles of $P$. longicirratus extend posterior to the posterior testis, so, it does not fit into Gaevskayatrema Gibson \& Bray, 1982 (Gibson \& Bray, 1982; Cribb, 2005). We have transferred the two species to Macvicaria and included them in Group C.

Group D. Species with vitelline follicles interrupted bilaterally in the ventral sucker region, tandem testes and a cirrus-sac not extending posterior to the ventral sucker: Macvicaria antarctica (Kovaljova \& Gaevskaya, 1974) Zdzitowiecki, 1990; M. geor- 
giana (Kovaljova \& Gaevskaja, 1974) Zdzitowiecki, Pisano \& Vacchi, 1992; M. heronensis Bray \& Cribb, 1989; M. issaitschikowi (Layman, 1930) Bray, 1985; M. muraenolepidis Zdzitowiecki, 1990; M. selachophidii Reimer, 1987.

Comments: Macvicaria selacophidii was figured and described by Reimer (1987) from a single specimen with no clear indication of the anterior limit of the vitelline follicles. It is not certain if this worm belongs in Macvicaria, but we have placed it with other species in Group D because it shares some of their characteristics and also because we have observed variations within a single species of Macvicaria that include the absence of vitelline follicles from the forebody. Bray \& Cribb (1989) remarked that this worm was probably a species of Allopodocotyle Pritchard, 1966 because the vitelline follicles are posterior to the ventral sucker, we share their view, however, any conclusive remarks should await examination of more specimens. No other author appears to have commented on the status of this species.

Group E. Species with vitelline follicles bilaterally interrupted in the ventral sucker area, oblique testes and a cirrus-sac usually not extending posterior to the ventral sucker: Macvicaria dampieri Bray, 1990; M. japonica (Yamaguti, 1938) Bray \& Cribb, 1989; M. macassarensis (Yamaguti, 1952) Bray \& Cribb, 1989; M. pennelli (Leiper \& Atkinson 1914) Zdzitowiecki, 1987; M. branchiostegi (Yamaguti, 1937) Bray, 1990.

Comments: $M$. pennelli was figured and described as having oblique testes by Gibson (1976) and oblique or tandem testes by Zdzitowiecki (1990) and Zdzitowiecki et al. (1992). Gibson (1976) described the cirrus-sac as reaching posteriorly to a level between middle and posterior margin of the ventral sucker; Zdzitowiecki (1990) made the same observation and mentioned that the cirrus-sac sometimes extended posterior to the posterior margin of the ventral sucker. The distribution of the vitelline follicles in this worm varies; the lateral fields may be continuous, as figured by Gibson (1976), or may be interrupted, as figured by Zdzitowiecki (1990) who observed both conditions in his material.

Yamaguti (1937) described the vitelline follicles in M. branchiostegi as surrounding the posterior portion of the oesophagus and entire length of the intestine. There is a slight indication of lateral interruption in the area of the ventral sucker in his figure. For this reason, we have placed this worm in the same group as other species whose lateral vitelline fields are interrupted in the area of the ventral sucker (Group E).

Group F. Species of Plagioporus (sensu lato) which conform with Gibson \& Bray's (1982) definition of Macvicaria in every way except in their very tiny eggs; P. interruptus Manter, 1954; and in the distribution of vitelline follicles; P. (Plagioporus) kyusen Yamaguti, 1959; and Plagioporus sp. of Al-Yamani \& Nahhas (1981). Bray (1985) remarked that the latter form resembled Macvicaria but refrained from transferring it to this genus, suggesting that it required further study before a definite decision can be made regarding its status.

\section{Macvicaria shotteri $\mathrm{n}$. sp.}

Type-host: Apogon fasciatus (White) (Apogonidae).

Other hosts: Sillaginodes punctatus (Cuvier) (Sillaginidae), Sillago bassensis Cuvier (Sillaginidae). 
Type-locality: Moreton Bay, off Tangalooma, Queensland, $27^{\circ} 14^{\prime} \mathrm{S}, 153^{\circ} 19^{\prime} \mathrm{E}$.

Other localities: Off Mandurah, 32³1'S, 115\%41'E \& off Point Peron, Western Australia, $32^{\circ} 18^{\prime} \mathrm{S}, 115^{\circ} 38^{\prime} \mathrm{E}$., off American River, South Australia $35^{\circ} 48^{\prime} \mathrm{S} 137^{\circ} 46^{\prime} \mathrm{E}$. Site: Intestine/gut.

Material studied: Ex Apogon fasciatus: From Moreton Bay, Queensland: 8 Off Tangalooma, February \& December, 1993; Ex Sillaginodes punctatus: From Western Australia: 8 Off Point Peron, 1 Off Mandurah Rockwall, December 1994. From South Australia: 12 Off American River, December 1995; Ex Sillago bassensis: From Western Australia: 3 Off North Mole, Fremantle, December 1994.

Type-material: Holotype: QM G223130, Paratypes: QM G 223131-223153, G230363-

G230375; BMNH 2008.7.5.20-38.

urn:lsid:zoobank.org:act:EB4EA8A7-38FA-48F9-AE5B-6F0952DB7ECF

Description (Figs 1-6)

Based on 16 mature and 4 juvenile unflattened, whole-mount specimens and 1 set each of serial sagittal sections from Sillaginodes punctatus. Measurements of worms from Sillago bassensis and Apogon fasciatus are given in Table 1.

Measurements are of 10 gravid, unflattened, dorso-ventrally mounted worms from Sillaginodes punctatus. Body elongate, oval, maximum width usually in area of gonads, sometimes in ventral sucker area, 1,345-2,062 (1,786) × 366-546 (479); width to length ratio 1:3.1-4.2 (3.7). Oral sucker globular, ventrally subterminal, 124-178 $(143) \times 132-194$ (157). Ventral sucker sub-spherical, in anterior third of body, 184$267(221) \times 218-311(256)$, sucker width ratio 1:1.5-1.7 (1.6). Forebody short, 371550 (449) long, 21.8-29.7 (25.3)\% of body-length. Prepharynx distinct, short, dorsal to oral sucker. Pharynx subglobular, 65-97 (77) $\times$ 78-117 (98); pharynx to oral sucker width ratio 1:1.4-1.7 (1.6). Oesophagus distinct, short. Intestinal bifurcation 48-156 (107) anterior to ventral sucker. Caeca terminate blindly close to posterior extremity.

Testes 2 , usually contiguous, rarely separate $(n=1)$, tandem, with entire to incised anterior and posterior margins, anterior 137-282 (201) $\times 155-286(239)$, posterior 184-338 (250) × 170-337 (244). Post-testicular region 312-498 (406) long, 19-27.4 (22.9)\% body-length. Cirrus-sac clavate, thick walled, overlaps ventral sucker dorsally and extends posteriorly to point anterior to or slightly posterior to posterior margin of ventral sucker, 294-528 (403) × 64-142 (99). Internal seminal vesicle tubular, convoluted, fills most available space in posterior half of cirrus-sac. Pars prostatica distinct, small, surrounded by prostatic cells. Ejaculatory duct long, thick walled. Genital atrium small. Genital pore sinistral to and level with posterior end of oesophagus, anterior to intestinal bifurcation, 200-300 (251) from anterior end, 11.6-18.4 (14.2)\% body-length.

Ovary entire, spherical, contiguous with and antero-dextral to anterior testis, 109$208(145) \times 98-194$ (144). Mehlis' gland well developed, seen clearly in juvenile worms and sagittal sections, obscured by eggs in gravid whole-mounts, dorsally antero-sinistral and partly anterior to ovary. Canalicular seminal receptacle large, saccular, may be entirely dorsal or sinistral to ovary, overlapping left margin of ovary and anterior margin 
of anterior testis. Laurer's canal present. Eggs oval, operculate, 54-79 (65) × 29-49 (37). Metraterm distinct, well developed, relatively long. Vitelline follicles extend from 176282 (229) from anterior extremity, 10.9-15.4 (12.9)\% of body-length, to 10-55 (21) from posterior extremity; fields separate ventrally in forebody, confluent dorsally in forebody and post-testicular area; continuous follicle-free zone between ventral sucker and posterior margin of posterior testis, dorsally; follicles lie lateral, ventral and dorsal to caeca; anterior extent usually level with, or slightly anterior to or posterior to posterior margin of pharynx, rarely posterior to posterior limit of oesophagus $(n=1)$.

Excretory pore dorsally subterminal. Excretory vesicle I-shaped, narrow posterior end surrounded by gland-cells, widens anteriorly and passes to point antero-dorsal to posterior margin of ovary.

Table I. Measurements (in $\mu \mathrm{m}$ ) of Macvicaria shotteri $\mathrm{n}$. sp. from Sillago bassensis ( $\mathrm{n}=2)$ and Apogon fasciatus $(\mathrm{n}=8)$.

\begin{tabular}{l|c|c|c|c|c|c}
\hline \multirow{2}{*}{ Host species } & \multicolumn{3}{|c|}{ S. bassensis } & \multicolumn{3}{c}{ A. fasciatus } \\
\cline { 2 - 7 } & Min. & Max & Mean & Min. & Max. & Mean \\
\hline Total length & 2,204 & 2,326 & 2,265 & 1,393 & 1,852 & 1,669 \\
Maximum width & 582 & 712 & 647 & 368 & 448 & 413 \\
Length/width & 3.1 & 4.0 & 3.5 & 3.4 & 4.3 & 4.0 \\
Oral sucker length & 159 & 188 & 174 & 122 & 149 & 132 \\
Oral sucker width (OSW) & 177 & 196 & 187 & 135 & 147 & 144 \\
Pharynx length & 87 & 101 & 94 & 64 & 83 & 71 \\
Pharynx width & 116 & 127 & 122 & 81 & 102 & 92 \\
OSW/pharynx width & 1.5 & 1.5 & 1.5 & 1.4 & 1.7 & 1.6 \\
Ovary length & 201 & 227 & 214 & 117 & 162 & 144 \\
Ovary width & 171 & 182 & 177 & 117 & 160 & 145 \\
Anterior testis length & 243 & 284 & 264 & 134 & 205 & 173 \\
Anterior testis width & 272 & 292 & 282 & 147 & 230 & 194 \\
Posterior testis length & 339 & 353 & 346 & 147 & 234 & 209 \\
Posterior testis width & 252 & 265 & 259 & 128 & 237 & 190 \\
Forebody-length (FBL) & 433 & 475 & 454 & 320 & 441 & 385 \\
FBL as \% of body-length & 18.6 & 21.6 & 20.1 & 20.9 & 25.8 & 23.1 \\
Ventral sucker length & 251 & 270 & 261 & 203 & 224 & 214 \\
Ventral sucker width (VSW) & 284 & 331 & 308 & 225 & 262 & 244 \\
VSW/OSW & 1.6 & 1.7 & 1.6 & 1.6 & 1.8 & 1.7 \\
Anterior extremity to genital pore (AEGP) & 258 & 277 & 268 & 188 & 246 & 223 \\
AEGP as \% body-length & 11.1 & 12.6 & 11.8 & 12.5 & 15.8 & 13.4 \\
Cirrus-sac length & 518 & 518 & 518 & 285 & 415 & 352 \\
Cirrus-sac width & 176 & 176 & 176 & 71 & 110 & 90 \\
Intestinal bifurcation to ventral sucker & 103 & 117 & 110 & 32 & 91 & 64 \\
Post-testicular region (PTR) & 501 & 632 & 567 & 333 & 525 & 426 \\
PTR as \% of body-length & 22.7 & 27.2 & 25.0 & 20.4 & 28.3 & 25.5 \\
Anterior extremity to vitellarium (AEV) & 276 & 317 & 297 & 230 & 307 & 263 \\
AEV as \% of body-length & 11.9 & 14.4 & 13.1 & 13.4 & 20.7 & 15.9 \\
Posterior extremity to vitellarium & 13 & 19 & 16 & 13 & 58 & 25 \\
Eggs & $62-76$ & $(69)$ & 37 & -48 & $58-72$ & $(64) \times 32-45$ \\
& & $(42), \mathrm{n}=11$ & & & $(38), \mathrm{n}=66$ & \\
\hline & & & & & & \\
& & & &
\end{tabular}



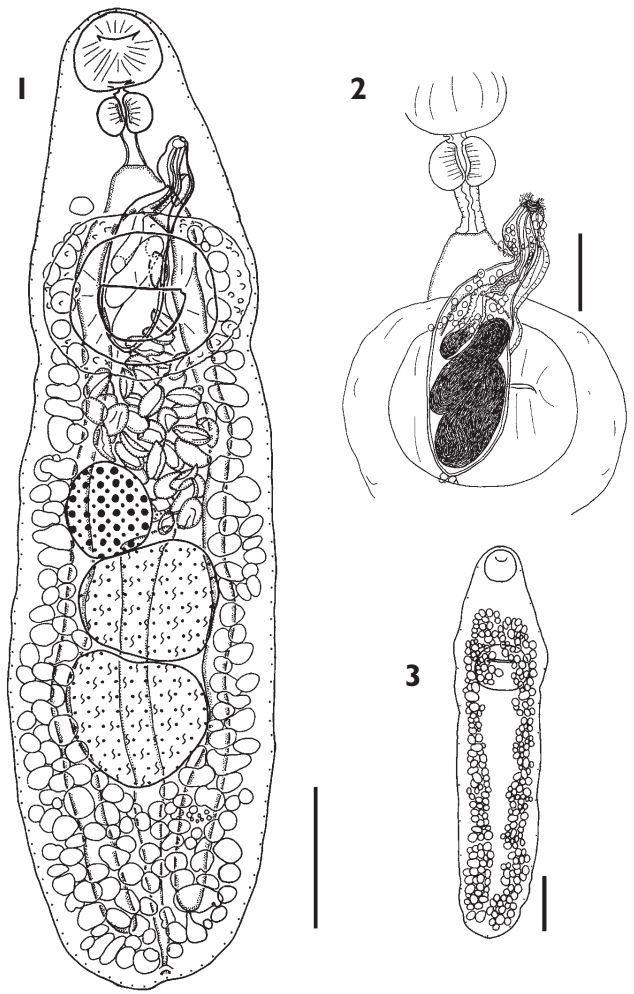

Figs I-3. Macvicaria shotteri n. sp. ex Apogon fasciatus. 1. Whole-mount ventral view. 2. Terminal genitalia. 3. Dorsal distribution of vitelline follicles. Scale bars: 1, 3, $250 \mu \mathrm{m} ; 2,100 \mu \mathrm{m}$.
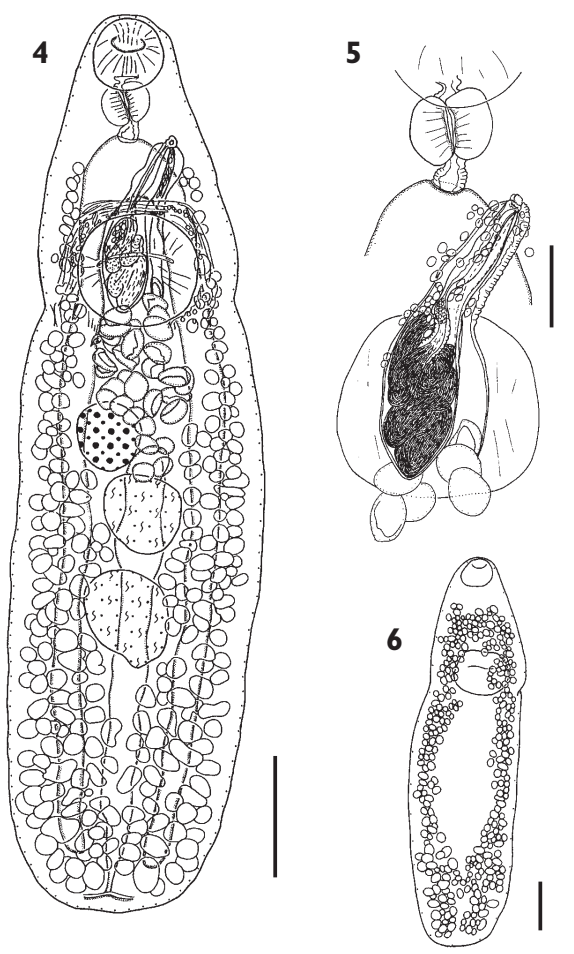

Figs 4-6. Macvicaria shotteri n. sp. ex Sillaginodes punctatus. 4 . Whole-mount ventral view. 5. Terminal genitalia. 6. Dorsal distribution of vitelline follicles. Scale bars: 4, 6, $250 \mu \mathrm{m} ; 5,100 \mu \mathrm{m}$.

Etymology: This species is named for Professor R. A. Shotter.

Comments: The specimens of Macvicaria shotteri from Sillago bassensis and Apogon fasciatus are similar to those from Sillaginodes punctatus except in a few morphological details which we do not consider to be of taxonomic importance, since most of the measurable features are comparable. The largest worms, the two from Sillago bassensis, had the largest eggs, whereas the eggs in the worms from Sillaginodes punctatus and Apogon fasciatus were similar in size. The worms from Sillaginodes punctatus had the longest forebody, 21.8-29.7 (25.3) \% of the body-length compared with 20.9-25.8 (23.1)\% and 18.6-21.6 (20.1)\% of the body-length in the worms from Sillago bassensis and those from $A$. fasciatus respectively. The testes are usually contiguous in worms from all three hosts except in two worms, one each from Sillaginodes punctatus and $A$. fasciatus in which the testes are separate. Bray (1985) observed that larger specimens of $M$. taksengi had larger eggs than the smaller specimens. This may also be the case in $M$. shotteri, since the largest eggs were in the largest worms from Sillago bassensis. Although the sharing of this parasite between apogonid and sillaginid hosts is surprising, we can find no morphological basis to interpret these specimens as two different species. 
Macvicaria shotteri $\mathrm{n}$. sp. fits into the concept of Group B as outlined above. This species can be distinguished from the other worms in the group as follows:

M. aegyptensis, according to Shalaby \& Hassanine (1997), is a less elongate worm with a width to length ratio of 1:2.2-2.8, a longer forebody, (33\% of body-length), a larger ventral sucker with sucker-width ratio of (1:2), and a genital pore at about $21 \%$ of the body-length from the anterior end.

M. crassigula, according to Bartoli et al. (1989), is a less elongate worm with a width to length ratio of 1:2.1 [2.44], it has a longer forebody (32\% [40\%] of body-length), a longer post-testicular space ( $27 \%$ of body-length), a slightly larger oral sucker with a sucker-width ratio of 1:1.27-1.40 [1.28], and a genital pore which is more posteriorly situated than in $M$. shotteri n. sp., at $26 \%$ of body-length from the anterior extremity.

M. chrysophrys, according to Nagaty \& Abdel-Aal (1969) and Hassanine \& Gibson (2005), is a less elongate species with a width to length ratio of 1:2.3 [2.7-2.9]; it has a longer forebody (39 [31-43]\% of the body-length); a shorter post-testicular area (17\% of body-length $)$ and larger eggs $(80 \times 50$ [64-78 × 35-48 $(71 \times 42)]$.

M. cynoglossi, according to Madhavi (1975), is relatively narrower with a width to length ratio of 1:4.17-4.59, with a longer forebody at $32-33 \%$ of the body-length, a generally greater sucker ratio at 1:1.6-2.0, lobed, oblique testes and a subterminal excretory pore (at the level of the caecal ends in the illustration).

M. dactylopagri, according to Manter (1954), is clearly differentiated from M. shotteri n. sp. by the anterior extent of the vitellarium which reaches to the oral sucker or pharynx.

M. dubia, according to Bartoli et al. (1989), is a less elongate worm with a width to length ratio of 1:2.1, a longer forebody and a shorter post-testicular area of $40 \%$ and $14 \%$ of the body-length, respectively, it has larger eggs, 71-85 × 33-43 $(79 \times 39)$, and a genital pore which is more posteriorly situated, at $29 \%$ of the body-length from anterior extremity.

M. eleuthoronemae, according to Wang et al. (1992), differs from M. shotteri n. sp. in the intestinal bifurcation being in the middle of a long forebody (35\% of bodylength), a short post-testicular region ( $14 \%$ of body-length) and all the gonads in the final third of the body.

M. hunghuaensis, according to Shen \& Qiu (1995), is a squat worm (width to length ratio of 1:2.1-3.0 (1:1.6 in illustration)). The cirrus-sac is confined to the forebody and the vitelline fields are widely separated.

M. longicauda, according to Hafeezullah (1971), is relatively narrower with a width to length ratio of 1:4.2-4.4, a slightly longer forebody at $29-30 \%$ of body-length, a long post-testicular region at $33 \%$ of body-length and the cirrus-sac does not reach the ventral sucker.

M. maillardi, according to Bartoli et al. (1989), has no distinct oesophagus, it has a smaller ventral sucker and a larger oral sucker shown by a sucker ratio of 1:1.06-1.48 (1.22), it has a longer forebody and shorter post-testicular area measuring $40 \%$ and $18 \%$ of the body-length, respectively, and a more posteriorly situated genital pore at $29 \%$ of the body-length from the anterior extremity.

M. mormyri, according to Bartoli et al. (1993), is a less elongate species, with a width to length ratio of 1:2.8, a smaller ventral sucker and larger oral sucker with a 
sucker width ratio of 1:1.16-1.54 (1.35); it has a longer forebody, $35 \%$ of the bodylength, and a genital pore which is more posteriorly situated at $19 \%$ of the body-length from anterior extremity.

M. obovata, according to Bartoli et al. (1989), is less elongate with a width to length ratio of 1:2.8, it has a longer forebody (37\% of the body-length), and a genital pore which is more posteriorly situated at $23 \%$ of the body-length from the anterior extremity.

M. ophthalmolyci, according to Zdzitowiecki $(1990,1997)$, has a very large ventral sucker (width ratio 1:2.1-2.7), a very short forebody (about 13\% of body-length) and the vitellarium reaches the pharynx.

M. taksengi, according to Bray (1985), is very close M. shotteri from which it can be distinguished by its smaller size $(590-1,110 \times 240-480)$, its less elongate form with a width to length ratio of $1: 2.5$, by its ovary which is situated dextrally or overlapping the anterior testis and by the distal expansion of the cirrus-sac.

M. sillagonis, according to Yamaguti (1938), is closest to M. shotteri from which it can be distinguished by its less elongate form, with a width to length ratio of 1:2.3, a slightly shorter post-testicular area of $20 \%$ of the body-length and a slightly smaller pharynx with a pharynx to oral sucker width ratio of 1:2.0.

The seminal vesicle in the new species is distinctive, in that it is thrown into two or more virtually parallel diagonal slings within the cirrus-sac, a feature not observed in $M$. sillagonis. Bray (1985) had commented that the holotype and two specimens of $M$. sillagonis which he examined were so extremely flattened that some of the features of the worms might have been altered; however, we do not think that the alteration will be so much as to unravel the slings of the seminal vesicle, if present in $M$. sillagonis.

\section{Macvicaria mekistomorphe $\mathrm{n} . \mathrm{sp}$.}

Type-host: Sillago maculata Quoy \& Gaimard (Sillaginidae).

Type-locality: Off Tangalooma, Moreton Bay, S. E. Queensland. $27^{\circ} 14^{\prime}$ S, $153^{\circ} 19^{\prime} \mathrm{E}$. Site: Intestine.

Material studied: 4 from Off Tangalooma, December 1993.

Type-material: Holotype: QM G230376, paratypes: QM G230377-230378, BMNH 2008.7.5.39.

urn:Isid:zoobank.org:act:5D0A5349-4643-4587-B3FB-04CD482451D0

Description (Figs 7-9)

Based on 4 gravid, whole-mount specimens from Sillago maculata. Measurements are of 4 gravid, unflattened whole-mount worms.

Body elongate oval; width recorded from area of gonads although greatest in region of the ventral sucker, 1440-1904 (1724) $\times$ 287-382 (346); width to length ratio 1:4.7-5.2 (5.0). Tegument with irregularly dispersed papillate structures. Oral sucker ventrally subterminal, sub-spherical, 109-154 (130) × 122-160(141). Ventral sucker larger than oral sucker, transversely oval, borne on slight eminence, in anterior third of body, 160-218 (189) × 192-237 (211); sucker width ratio 1:1.4- 
1.6 (1.5). Forebody relatively short, 371-467 (414) long, 24.5-25.8 (24.9)\% bodylength. Prepharynx, indistinct, short, may be entirely dorsal or posterior to oral sucker. Pharynx well developed, sub-spherical, 77-102 (90) × 83-128 (107); pharynx to oral sucker width ratio 1:1.2-1.5 (1.3). Oesophagus short, thick walled. Intestinal bifurcation 55-104 (81) anterior to ventral sucker. Caeca terminate blindly close to posterior extremity.

Testes 2 , entire, usually separate, occasionally contiguous $(\mathrm{n}=1)$, tandem, in posterior half of body, anterior 134-173 (154) × 128-154 (141); posterior 154-192 (170) $\times$ 125-173 (142). Post-testicular area 339-512 (426) long, 21.0-26.9 (24.5)\% bodylength. Cirrus-sac well developed, claviform, extends from point sinistral to oesophagus, overlapping ventral sucker dorsally usually to point just anterior to or level with its posterior margin, occasionally to ventral sucker aperture $(n=1), 272-305(294) \times 71-78$ (75). Internal seminal vesicle tubular; anterior portion narrower than posterior, loops once, occupies most of broad posterior portion of cirrus-sac. Pars prostatica distinct, narrow, surrounded by gland cells. Ejaculatory duct well developed, surrounded by numerous gland cells. Genital atrium distinct, small. Genital pore antero-sinistral to caecal bifurcation, may be level with posterior margin of pharynx, or on outer margin
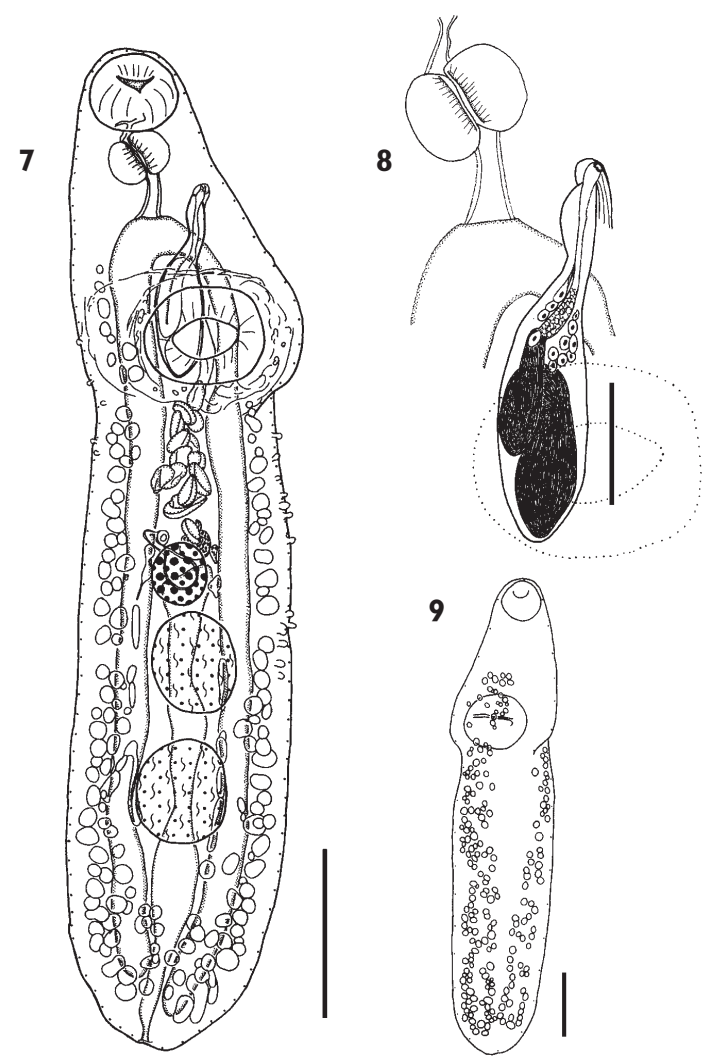

Figs 7-9. Macvicaria mekistomorphe n. sp. ex Sillago maculata. 7. Whole-mount ventral view. 8. Terminal genitalia. 9. Dorsal distribution of vitelline follicles. Scale bars: 7, 9, $250 \mu \mathrm{m} ; 8,100 \mu \mathrm{m}$. 
of left caecum and more or less level with posterior limit of oesophagus, 220-298 (251) from anterior end, 13-16 (15)\% of body-length.

Ovary entire, sub-spherical, anterior to and usually separated from anterior testis, occasionally contiguous with anterior testis $(n=1)$, 90-134 (111) × 77-128 (101). Mehlis' gland feebly developed, anterior to ovary. Canalicular seminal receptacle large, saccular, elongate, oval, usually overlaps ovary dorsally, occasionally displaced entirely sinistral to ovary $(n=1)$, may extend posteriorly to overlap anterior margin of anterior testis or terminate close to posterior margin of ovary. Laurer's canal present. Uterus coils intercaecally between anterior margin of ovary and posterior margin of ventral sucker, usually overlapping caeca dorsally and leading to genital pore without coiling. Eggs oval, operculate, 58-70 (63) × 26-29 (26). Metraterm indistinct. Vitelline follicles extend from 294-378 (336) from anterior extremity, 15.4-22.2 (19.7)\% of body-length, to 38-67 (54) from posterior extremity; follicles feebly developed, particularly in forebody; fields mostly separate in hindbody, more or less confluent in posttesticular area dorsally and ventrally; follicles lie lateral to caeca mostly, with anterior limit at about level of intestinal bifurcation.

Excretory pore ventrally subterminal to terminal. Excretory vesicle I-shaped, anterior limit dorsal to posterior half of ovary, leads to pore through narrow duct.

Etymology: The species name (Gr. mekistos, longest; Gr. morphe, shape) is derived from the fact that this species is the most elongate worm in its group.

Comments: All the four specimens on which the description of Macvicaria mekistomorphe n. sp. was based were covered in irregularly dispersed papillate structures of unknown origin. Some of the structures appeared to contain nuclei, suggesting infection by a unicellular organism, whereas others appeared anucleate, suggesting the occurrence of tegumental papillae which may have been caused by fixation. Aside from the papillate structures, the vitelline follicles in all four specimens of this worm appeared to be poorly developed. It is not certain if the nature of the tegument is in any way related to that of the vitellarium or if the two conditions arose independently. None of the other Sillago species examined were infected by this worm, so it was not possible to determine whether or not the two features were characteristic of $M$. mekistomorphe $\mathrm{n}$. sp. or if they were induced by the particular fish from which they were collected.

Macvicaria mekistomorphe fits into the concept of Group B as defined above. It can be distinguished from all the other species of Macvicaria in the group by its distinctly more elongate form, with a width to length ratio of 1:4.7-5.2 (5.0). The next most elongate species, $M$. ophthalmolyci, has a width to length ratio of 1:3.3-5.0 (4.1), but it can be distinguished from this and all other species in the group by its short forebody and large ventral sucker. The new species can be distinguished further from the other species by its usually separate testes and the ovary which is usually separated from and is more or less medially anterior to the anterior testis. The seminal vesicle in the new species is also distinctive as it forms a single loop medially. In the last feature, $M$. mekistomorphe resembles $M$. taksengi, which is less elongate, has a width to length ratio of $1: 3.1$, and has larger eggs $(67-80 \times 32-53)$. 


\section{Macvicaria mutovitellina $\mathrm{n}$. sp.}

Type-host: Dactylophora nigricans (Richardson) (Cheilodactylidae).

Type-locality: Off Point Peron, Western Australia $32^{\circ} 18^{\prime}$ S, $115^{\circ} 38^{\prime} \mathrm{E}$.

Site: Intestine.

Material studied: 14 Off Point Peron, December 1994.

Type-material: Holotype: QM G230379, paratypes: QM G230380-230389, BMNH 2008.7.5.1-5.

urn:Isid:zoobank.org:act:604CFAD5-C948-4547-846D-47E9F8A10091

Description (Figs 10-15)

Based on 13 gravid, whole-mount specimens and 1 set of serial sagittal sections. Measurements are of 10 gravid, unflattened, whole-mount worms.

Body robust, elongate-oval, sub-cylindrical, tapered at anterior end, rounded at posterior end, lateral margins roughly parallel, 833-1,108 (962) × 296-393 (349); width to length ratio 1:2.5-3.0 (2.8). Oral sucker almost terminal, subglobular, 95-123 $(110) \times 116-148(131)$. Ventral sucker larger than oral sucker, transversely oval, 183$228(203) \times 207-261(228)$; sucker width ratio 1:1.6-1.9 (1.7). Forebody contains few large and numerous small gland cells, 227-281 (261) long, 25-29 (27)\% body-length.
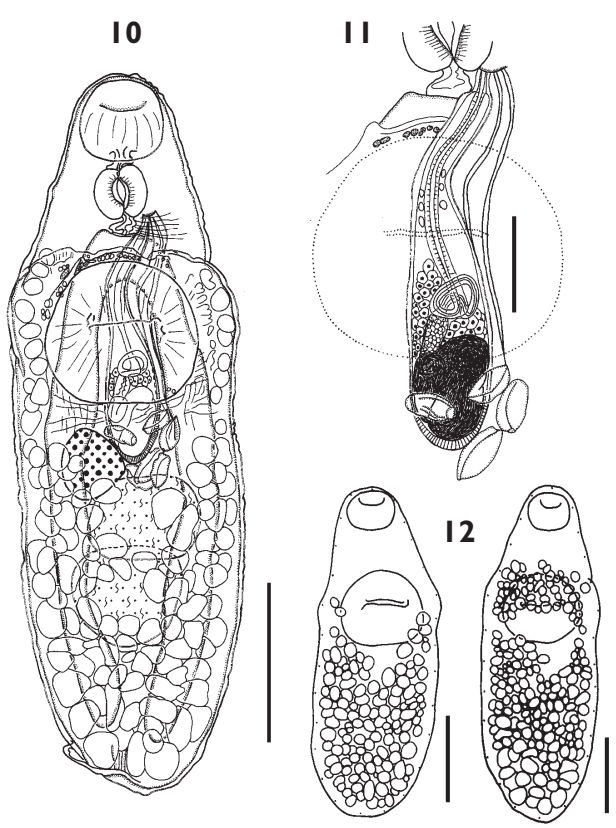

Figs 10-I2. Macvicaria mutovitellina n. sp. ex Dactylophora nigricans. 10. Whole-mount ventral view. 11. Terminal genitalia. 12. Dorsal distribution of vitelline follicles. Scale bars: 10, 12, $250 \mu \mathrm{m}$; $11,100 \mu \mathrm{m}$.
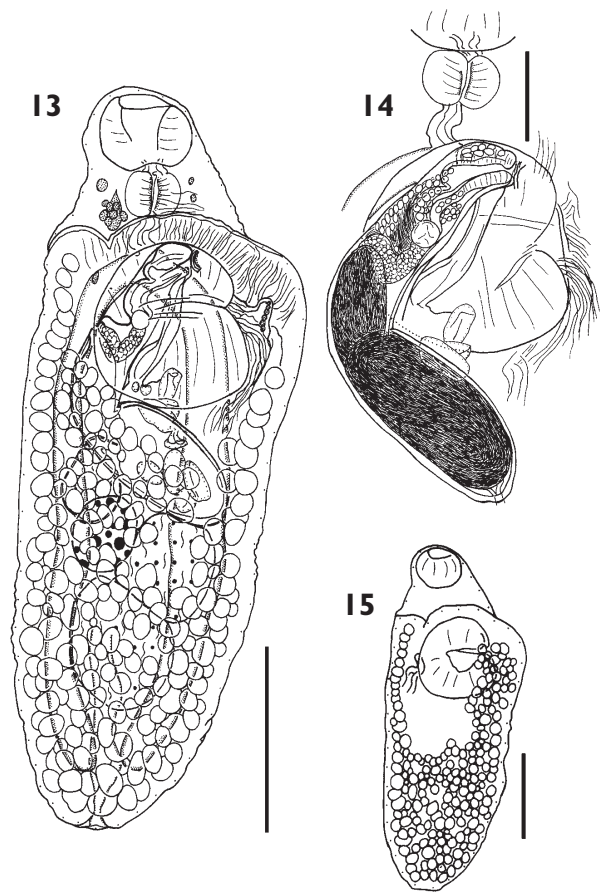

Figs 13-15. Macvicaria mutovitellina n. sp. ex Dactylophora nigricans. 13. Whole-mount ventral view. 14. Terminal genitalia. 15. Dorsal distribution of vitelline follicles. Scale bars: 13, 15, $250 \mu \mathrm{m}$; $14,100 \mu \mathrm{m}$. 
Prepharynx distinct, short, partly posterior and partly dorsal to oral sucker. Pharynx large, sub-spherical, 63-80 (71) × 71-99 (81); pharynx to oral sucker width ratio 1:1.51.8 (1.6). Oesophagus distinct, short, thick walled. Intestinal bifurcation usually dorsal to anterior half of ventral sucker, 15-29 (21) posterior to anterior margin of ventral sucker, sometimes level with $(n=4)$, and occasionally just anterior to anterior margin ventral sucker $(n=1)$. Caeca terminate blindly close to posterior extremity.

Testes 2, transversely oval, tandem, contiguous, entire, anterior 101-159 (122) × 136-190 (172), posterior 133-167 (148) × 151-188 (174). Post-testicular area 138246 (180) long, 15-22 (19) \% body-length. Cirrus-sac large, clavate, thick walled especially at posterior extremity, extends from about level of posterior margin of pharynx to level of ovary or anterior testis; 306-388 (347) $\times$ 78-104 (88). Internal seminal vesicle convoluted, occupies posterior half or third of cirrus-sac. Pars prostatica distinct, well developed, surrounded by numerous gland cells. Ejaculatory duct long, convoluted at posterior end, thick walled, surrounded by few gland cells. Genital atrium small. Genital pore extra-caecal, antero-sinistral to intestinal bifurcation, usually anterior to posterior margin of pharynx, sometimes level with oesophagus $(n=3), 169-231$ (200) from anterior end, 20-22 (21)\% of body-length.

Ovary entire, spherical to sub-spherical, usually contiguous with anterior testis, sometimes separate $(\mathrm{n}=2)$, usually antero-dextral to anterior testis, occasionally dextral $(\mathrm{n}=1), 81-111(94) \times 89-112(103)$. Mehlis' gland distinct, sinistral to ovary, anterior to anterior testis. Canalicular seminal receptacle small, saccate, dorsal to anterior testis. Uterine coils usually extend from point just posterior to anterior margin of anterior testis to posterior margin of ventral sucker, overlapping left caecum ventrally and sometimes left side of ovary dorsally, occasionally coils extend to just anterior to posterior margin of anterior testis $(n=1)$ or to posterior margin of posterior testis $(n=1)$. Metraterm distinct, moderately long, well developed, overlaps left caecum to point just anterior to or just posterior to ventral sucker aperture. Eggs relatively large, tanned, usually few, oval, operculate, 54-71 (63) × 26-39 (31). Vitelline follicles extend from 173-314 (215) from anterior extremity, 17-34 (22)\% body-length, to 8-19 (14) from posterior extremity; follicles in two separate fields in forebody ventrally, confluent in post-testicular area, covering almost all surface of posterior testis and posterior and or lateral portion of anterior testis and ovary ventrally; dorsal field almost confluent, interrupted in area of posterior half of ventral sucker, particularly in area of male terminal genitalia, sometimes follicles absent dorsally and ventrally $(n=1)$ or feebly developed $(n=2)$ in forebody; fields lie lateral, dorsal and ventral to caeca with unilateral or bilateral follicle-free patches in area of ventral sucker ventrally; anterior extent usually at level of posterior end of oesophagus, or posterior margin of pharynx, rarely at level of ventral sucker aperture $(n=1)$.

Excretory pore terminal. Excretory vesicle I-shaped, with narrow posterior end, broadens and extends anteriorly to point just posterior to anterior margin of anterior testis as seen in sagittal section.

Etymology: The species name mutovitellina (L. muto, change; vitellus, yolk) is derived from the variable patterns of the distribution of vitelline follicles. 
Comments: The distribution of vitelline follicles, posterior extent of cirrus-sac and arrangement of testes of Macvicaria mutovitellina $\mathrm{n}$. sp. is characteristic of worms in Group C. The following species can be readily distinguished from M. mutovitellina and the other members of the group:

M. longicirrata is a more elongate form with the longest forebody, smallest ventral sucker and the smallest post-testicular space (Manter, 1963).

$M$. longisaccus is also an elongate worm which can be distinguished from $M$. mutovitellina by its larger pharynx with a pharynx to oral sucker width ratio of $1: 1.3$, its slightly larger ventral sucker with a ventral sucker/oral sucker width ratio of 1:2.1, its longer forebody at $37 \%$ of body-length and a shorter post-testicular space at $18.0 \%$ of the body-length (Fischthal \& Kuntz, 1964)

M. gerridis has a body form similar to that of $M$. mutovitellina, a distinctly bipartite seminal vesicle and a shorter forebody (Fischthal \& Thomas, 1970). The only other species of Macvicaria which is reported to have a bipartite seminal vesicle is M. macassarensis in Group E.

M. synagris is closest to $M$. mutovitellina from which it can be distinguished by its body shape, much longer oesophagus, more conspicuous prepharynx, relatively narrower oral sucker and larger ventral sucker with a sucker width ratio of 1:2.5, caeca which do not reach well beyond the posterior margin of the posterior testis, a more anteriorly situated genital pore and an ovary separated from the anterior testis by the seminal receptacle (Yamaguti, 1952). Furthermore, the vitelline follicles in the new species are more profuse, partly covering the ventral surface of the gonads and just entering the forebody anteriorly, whereas in $M$. synagris the ventral surface of the gonads is free of vitelline follicles which reach anteriorly to a point just posterior to the posterior margin of the pharynx and extend further anteriorly than in the new species.

$M$. jagannathi is a more elongate worm with a width length ratio of $1: 4.7$, a shorter forebody of about $20 \%$ of body-length, separated gonads, the cirrus-sac just encroaching into the hindbody and a greater distance between the ovary and the ventral sucker (Gupta \& Singh, 1985).

M. longibursata has small eggs ( $42-40 \times 26-35)$, is relatively elongate (width: length ratio 1:4.6-4.7) and the vitellarium reaches to the oral sucker (Zdzitowiecki \& Cielecka, 1997).

$M$. deeghaensis is relatively elongate (width: length ratio 1:4.6-5.0), with a short forebody (about $17 \%$ of body-length), with separated gonads and a relatively long ventral sucker to ovary distance into which the cirrus-sac only encroaches slightly (Gupta \& Gupta, 1988).

M. skorai is similar to M. mutovitellina, but may be slightly more elongate (width: length ratio 1:2.53-4.16), the vitellarium reaches to the pharynx and is confluent in the forebody, the testes are distinctly oblique and the ventral sucker to ovary distance is slightly greater (Zdztowiecki, 1999).

\section{Macvicaria flexuomeatus n. sp.}

Type-host: Goniistius gibbosus (Richardson) (Cheilodactylidae).

Other host: Cheilodactylus rubrolabiatus Allen \& Heemstra (Cheilodactylidae).

Type-locality: Off Woodman Point, W. A. 3208'S 115²4'E 
Site: Gut, intestine.

Material studied: Ex Goniistius gibbosus: 17 from off Woodman Point, December 1994;

Ex Cheilodactylus rubrolabiatus: 3 from off Woodman Point, December, 1994.

Type-material: Holotype: QM G230390, paratypes: QM G230391-230403, BMNH 2008.7.5.6-13.

urn:Isid:zoobank.org:act:CD873C9A-5940-4EB8-B981-2317670F48F9

Description (Figs 16-20)

Based on 15 mature whole-mount specimens and 2 sets of serial sagittal sections from Goniistius gibbosus. Measurements of worms from Cheilodactylus rubrolabiatus are given in Table 2.

Measurements are of 10 gravid, unflattened whole-mount worms from Goniistius gibbosus. Body robust, oval, sub-cylindrical, maximum width in region of gonads, 688$1119(904) \times 316-481$ (408); width to length ratio 1:2.1-2.4 (2.2). Oral sucker ventrally subterminal, subglobular, 90-118 (105) × 112-159 (133). Ventral sucker larger

Table 2. Measurements (in $\mu \mathrm{m})$ of Macvicaria flexuomeatus $\mathrm{n}$. sp. $(\mathrm{n}=3)$ from Cheilodactylus rubrolabiatus.

\begin{tabular}{l|c|c|c}
\hline Total length & Min. & Max. & Mean \\
\cline { 2 - 4 } & 675 & 824 & 755 \\
\hline Maximum width & 305 & 384 & 340 \\
Length/width & 2.1 & 2.3 & 2.2 \\
Oral sucker length & 84 & 103 & 92 \\
Oral sucker width (OSW) & 107 & 113 & 109 \\
Pharynx length & 53 & 66 & 58 \\
Pharynx width & 60 & 68 & 63 \\
OSW/pharynx width & 1.7 & 1.8 & 1.8 \\
Ovary width & 62 & 96 & 84 \\
Anterior testis length & 81 & 134 & 109 \\
Anterior testis width & 119 & 160 & 144 \\
Posterior testis length & 108 & 128 & 119 \\
Posterior testis width & 125 & 156 & 137 \\
Forebody-length (FBL) & 187 & 220 & 206 \\
FBL as \% of body-length & 26.7 & 27.7 & 27.3 \\
Ventral sucker length & 165 & 183 & 176 \\
Ventral sucker width (VSW) & 189 & 212 & 203 \\
VSW/OSW & 1.8 & 2.0 & 1.9 \\
Anterior extremity to genital pore (AEGP) & 153 & 166 & 158 \\
AEGP as \% body-length & 18.6 & 23.0 & 21.1 \\
Cirrus-sac length & 256 & 289 & 275 \\
Cirrus-sac width & 74 & 83 & 78 \\
Post-testicular region (PTR) & 106 & 137 & 121 \\
PTR as \% of body-length & 15.7 & 16.6 & 16.0 \\
Anterior extremity to vitellarium (AEV) & 157 & 178 & 166 \\
AEV as \% of body-length & 21.2 & 23.3 & 22.0 \\
Posterior extremity to vitellarium & 8 & 16 & 12 \\
Eggs & $57-74$ & $(64)$ & $25-42(34), \mathrm{n}=12$ \\
\hline
\end{tabular}


than oral sucker, transversely oval, margin of anterior portion bordered by tegumental fold, supplied with numerous prominent muscle fibres, in anterior half of body, 169234 (205) × 206-256 (232); sucker width ratio 1:1.6-1.9 (1.7). Forebody short, 205297 (251) long, 26-30 (28)\% body-length. Prepharynx distinct, short, almost entirely dorso-posterior to oral sucker. Pharynx well developed, spherical to sub-spherical, 67$86(76) \times 68-99(83)$; pharynx to oral sucker width ratio 1:1.5-1.8 (1.6). Oesophagus short, thick walled, surrounded by few gland cells. Intestinal bifurcation usually posterior to anterior margin of ventral sucker, sometimes slightly anterior to $(\mathrm{n}=2)$ or level with anterior margin of ventral sucker $(n=1)$. Caeca broad, terminate blindly close to posterior extremity.

Testes 2 , rarely one $(n=1)$, spherical to sub-spherical, contiguous, overlapping, usually tandem or oblique, sometimes neither distinctly tandem nor oblique $(\mathrm{n}=2)$, in posterior half of body, anterior 88-143 (118) × 125-200 (164), posterior 109-181 (145) $\times 112-221$ (169), overlaps anterior testis dorsally. Post-testicular area small, 89-179 (137) long, 11-18 (15) \% body-length. Cirrus-sac large, claviform, thick walled particularly at posterior end, extends from point antero-sinistral to pharynx, reaching past ventral sucker dorsally, usually medially, sometimes laterally, to anterior margin of anterior testis, usually deflecting to left side at level of ovary, sometimes deflecting to right $(n=2)$, or not $(n=1)$; posterior tip may overlap ovary or anterior testis dorsally, depressing anterior margin of anterior testis at point of contact or wedged between ovary and
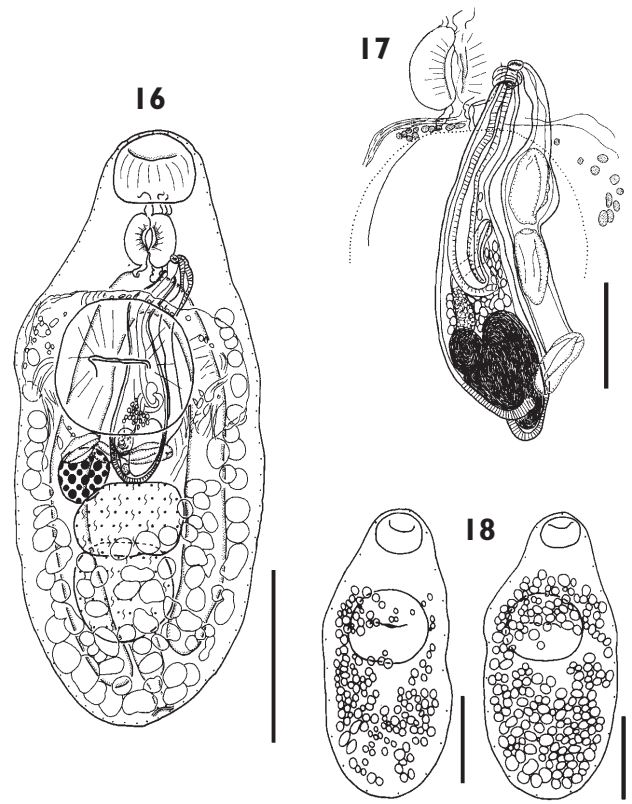

Figs 16-18. Macvicaria flexuomeatus n. sp. ex Goniistius gibbosus. 16. Whole-mount ventral view. 17. Terminal genitalia. 18. Dorsal distribution of vitelline follicles. Scale bars: 16, 18, $250 \mu \mathrm{m} ; 17,100 \mu \mathrm{m}$.
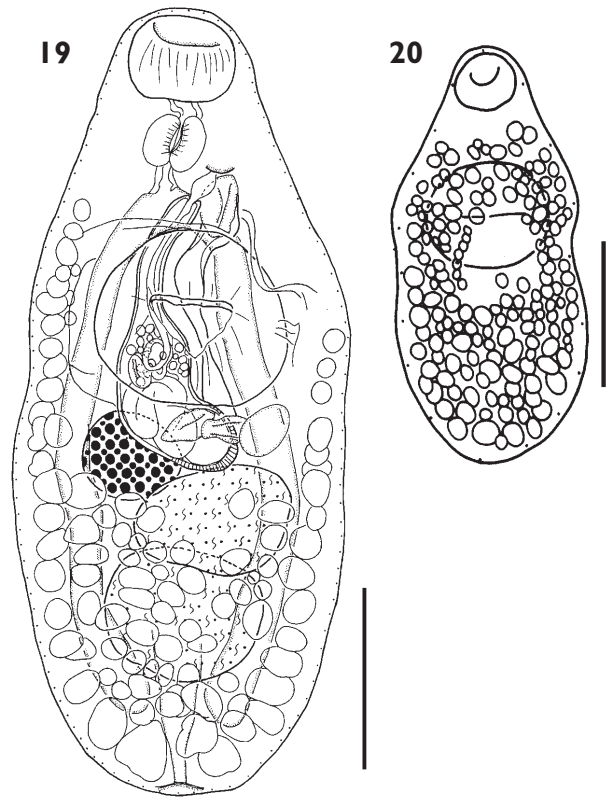

Figs 19-20. Macvicaria flexuomeatus n. sp. ex Cheilodactylus rubrolabiatus. 19. Whole-mount ventral view. 20. Dorsal distribution of vitelline follicles. Scale bars: 19, 20, $250 \mu \mathrm{m}$. 
anterior testis; 314-404 (351) × 76-101 (91). Internal seminal vesicle, tubular, occupies posterior portion of cirrus-sac. Pars prostatica well developed, thick walled, surrounded by numerous gland cells. Ejaculatory duct long, thick walled, convoluted at posterior end, surrounded by gland cells. Male terminal genitalia absent in one specimen. Genital atrium small, surrounded by few gland cells. Genital pore sinistral, extracaecal, at level of posterior half of pharynx, usually about half way between median and lateral margin, sometimes overlapping left margin of pharynx $(n=3)$; 157-220 (195) from anterior end, 20-23 (22)\% of body-length.

Ovary entire, spherical, normally smaller than testes, hypertrophied and about twice size of solitary testis in one worm, contiguous with, and dextral or antero-dextral to anterior testis, occasionally separated from $(\mathrm{n}=2)$ or anterior to anterior testis $(\mathrm{n}=1)$, 66-110 (88) × 67-114 (89). Mehlis' gland distinct, dorsal to ovary. Canalicular seminal receptacle large, saccate, usually dorsal to anterior testis, overlapping anterior portion of posterior testis, occasionally overlapping ovary and posterior testis dorsally $(n=1)$. Uterine coils mainly intercaecal, between anterior testis and posterior margin of ventral sucker, overlapping ovary, anterior testis and cirrus-sac ventrally and dorsally and, sometimes inner margins of caeca; coils may extend posteriorly to posterior margin of posterior testis $(n=1)$ or anteriorly to posterior portion of ventral sucker $(n=2)$. Metraterm distinct, thick walled, extensive, usually containing eggs, distal extremity surrounded by gland cells. Eggs large, oval, operculate, 50-75 (65) × 25-41 (32). Vitelline follicles extend from 163-247 (208) from anterior extremity, 21-27 (23)\% of bodylength, to 9-23 (13) from posterior extremity; fields separate ventrally in forebody, confluent in post-testicular area, covering almost all surface of posterior testis and posterior portion of anterior testis ventrally; dorsal field almost confluent throughout length, but interrupted in area of posterior half of ventral sucker, particularly in area of male terminal genitalia, sometimes follicles feebly developed on left or right side of forebody $(\mathrm{n}=2)$. Fields lie lateral, dorsal and ventral to caeca with bilateral follicle-free patches in area of ventral sucker ventrally; anterior extent of follicles usually level with posterior end of oesophagus, intestinal bifurcation or sometimes varying between posterior margin of ventral sucker and intestinal bifurcation, rarely to posterior margin of pharynx ventrally $(\mathrm{n}=1)$ or dorsally $(\mathrm{n}=2)$.

Excretory pore usually dorsally subterminal, sometimes terminal $(n=4)$, or occasionally ventrally subterminal $(\mathrm{n}=1)$. Excretory vesicle I-shaped, tubular, posterior end narrow, anterior portion broad, extends anteriorly to terminate just anterior to posterior margin of anterior testis as observed in sagittal section.

Etymology: The species name flexuomeatus (L. flexuosus, full of bends; L. meatus, passage) is derived from the species' characteristic convoluted ejaculatory duct.

Comments: The specimens of Macvicaria flexuomeatus n. sp. from Cheilodactylus rubrolabiatus are very similar to those from G. gibbosus; no significant visible or morpho-metrical differences were observed.

Macvicaria flexuomeatus n. sp. fits the concept of Group C.

M. synagris differs in its general body form (fusiform in M. synagris), sucker-ratio (1:2.5), and a more anterior genital pore ( $13 \%$ of body-length from the anterior extremity). 
Macvicaria mutovitellina is more elongate with a width to length ratio of 1:2.5-3.0 (2.8) and it has a longer post-testicular space (15-22 (19)\% of the body-length). The caeca in $M$. flexuomeatus terminate just beyond the posterior margin of the posterior testis whereas they reach well into the post-testicular space in $M$. mutovitellina.

The other members of Group C differ from M. flexuomeatus in the same features as they do M. mutovillina.

\section{Macvicaria vitellocopiosa $\mathrm{n}$. $\mathrm{sp}$.}

Type-host: Sillaginodes punctatus (Cuvier) (Sillaginidae).

Type-locality: Off American River, South Australia 3548'S, $137^{\circ} 46^{\prime} \mathrm{E}$.

Site: Intestine, gut.

Material studied: 8 Off American River, December 1995.

Type-material: Holotype: QM G230404, paratypes: QM G230405-230414, BMNH 2008.7.5.14-19.

urn:Isid:zoobank.org:act:E89B7000-D733-4028-9B49-8314E0337519

Description (Figs 21-23).

Based on 6 unflattened adult whole-mount specimens and 2 sets of serial sagittal sections and measurements of 5 gravid, unflattened, dorso-ventrally mounted worms.

Body oval, robust, sub-cylindrical, maximum width in region of gonads, 683-1,250 (978) $\times$ 254-475 (388); width to length ratio 1:2.4-2.7 (2.5). Oral sucker ventrally subterminal, subglobular, 96-142 (118) $\times 100-152(130)$. Ventral sucker pre-equatorial, larger than oral sucker, transversely oval, 149-233 (192) × 162-267 (220); sucker width ratio 1:1.6-1.8 (1.7). Forebody 209-322 (274) long, 25-31 (28)\% body-length. Prepharynx distinct usually entirely dorsal to oral sucker, sometimes posterior to ventral sucker $(\mathrm{n}=1)$. Pharynx well developed, large, spherical, 60-86 (76) × 62-93 (76); pharynx to oral sucker width ratio 1:1.6-1.8 (1.7). Oesophagus short, thick walled, surrounded by cluster of gland cells. Intestinal bifurcation almost level with anterior margin of ventral sucker, 3-37 (15) anterior to ventral sucker. Caeca broad, terminate blindly close to posterior extremity.

Testes 2, entire, usually more or less oblique, distinctly oblique in one specimen, contiguous, in posterior half of body, anterior often roughly triangular, 95-176 (147) $\times 108-212$ (167), posterior 100-226 (161) × 131-200 (171). Post-testicular area 106269 (181) long, 15-21 (18)\% body-length. Cirrus-sac elongate, claviform, extends from point sinistral to pharynx, overlapping ventral sucker dorsally, to point posterior to posterior margin of ventral sucker, almost to anterior margin of anterior testis, thick walled, particularly at rounded posterior end, 241-449 (329) $\times 73-123$ (95). Internal seminal vesicle tubular, occupies posterior third of cirrus-sac. Pars prostatica distinct, thick walled, surrounded by numerous gland cells. Ejaculatory duct long, thick walled, loops close to junction with pars prostatica. Genital atrium inconspicuous, small. Genital pore extra-caecal, antero-sinistral to intestinal bifurcation, at level of pharynx, 150253 (209) from anterior extremity, 18-24 (22)\% of body-length. 
Ovary entire, subglobular, contiguously antero-dextral or dextral to anterior testis, 79-128 (106) $\times$ 70-130 (104). Mehlis' gland indistinct, sinistral to ovary, anterior to anterior testis, just posterior to posterior tip of cirrus-sac, usually obscured by eggs. Canalicular seminal receptacle large, saccular, elongate oval, may be dorsal to ovary, or mostly dorsal to anterior testis overlapping right side of posterior testis dorsally. Uterine coils few, mainly between anterior testis and ventral sucker, overlapping caeca ventrally and anterior testis and left side of ovary dorsally. Eggs large, oval, operculate, 53-83 (71) × 30-52 (40). Metraterm well developed. Vitelline follicles extend from 143-255 (201) from anterior extremity, 18-23 (21)\% of body-length, to 18-23 (21) from posterior extremity; in 2 separate fields in forebody ventrally, confluent in posttesticular area and covering almost all surface of posterior testis and sides of anterior testis ventrally; dorsal field almost confluent, interrupted in the area of posterior half of ventral sucker only; lie lateral and dorsal to caeca and, ventral to caeca posterior to ventral sucker; anterior extent between posterior end of oesophagus and level of pharynx ventrally, almost to anterior margin of pharynx dorsally.

Excretory pore terminal. Excretory vesicle I-shaped, narrow posteriorly, widens anteriorly, anterior limit indiscernible in whole-mounts, terminates just posterior to anterior margin of anterior testis in sagittal section.
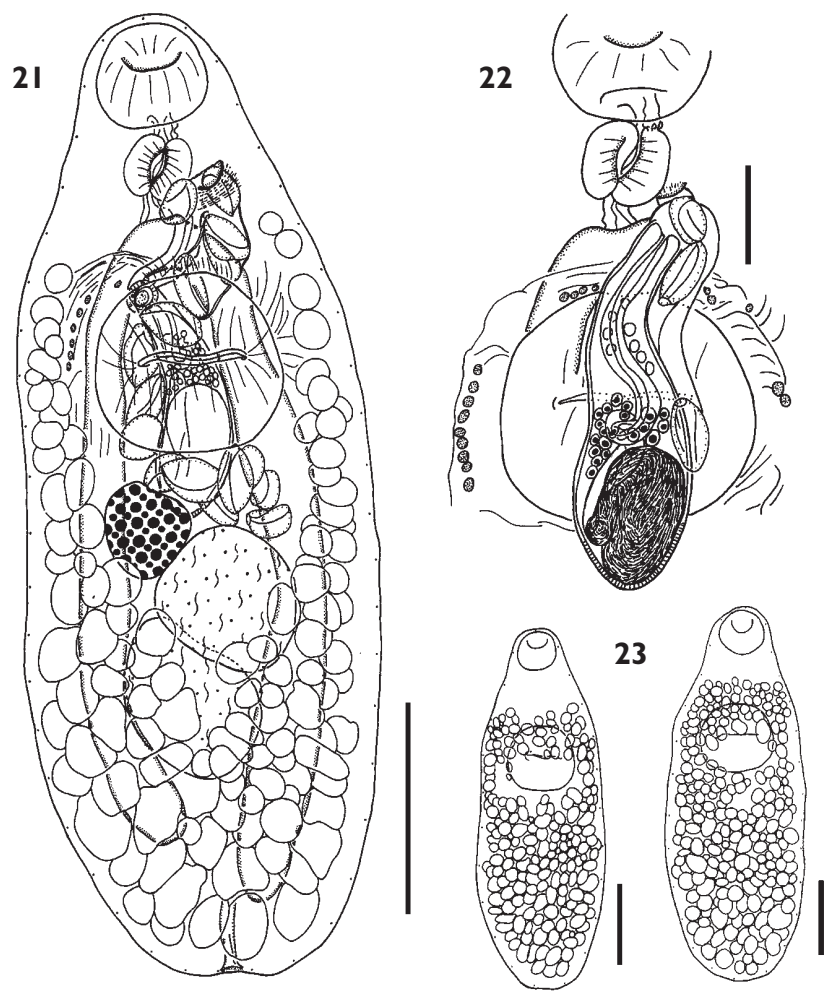

Figs 21-23. Macvicaria vitellocopiosa $\mathrm{n}$. sp. ex Sillaginodes punctatus. 21. Whole-mount ventral view. 22. Terminal genitalia. 23. Dorsal distribution of vitelline follicles. Scale bars: 21, 23, $250 \mu \mathrm{m}$; 22, $100 \mu \mathrm{m}$. 
Etymology: The species name vitellocopiosa (L. vitellus, yolk; L. copiosa, richly provided with) refers to the abundance of the vitelline follicles in the new species.

Comments: Macvicaria vitellocopiosa n. sp. can be accommodated in Group C. It is similar to M. synagris, M. mutovitellina and M. flexuomeatus in many features but can be distinguished from them as follows:

M. synagris is fusiform, it has a larger ventral sucker relative to the oral sucker with a sucker width ratio of 1:2.5; a slightly smaller post-testicular space, a more anteriorly situated genital pore, caeca which do not extend beyond the posterior margin of the posterior testis and it has shorter eggs (51-66 long) (Yamaguti, 1952).

$M$. flexuomeatus has a slightly less elongate form with a width to length ratio of 1:2.1-2.4 (2.2), a smaller post-testicular space at 11-18 (15)\% of body-length and smaller eggs at $50-75 \times 25-41(65 \times 32)$.

M. mutovitellina is a slightly more elongate form with a width to length ratio of 1:2.5-3.0 (2.8), with smaller eggs at 54-71 × 26-39 $(63 \times 31)$, a more conspicuous tegumental fold around the ventral sucker and less copious vitelline follicles..

M. skorai is more elongate with a width to length ratio of 1:2.5-4.2 (3.1), a shorter cirrus-sac that does not reach the ovary, short eggs at 43-55 $\times 23-35$ and shorter caeca which terminate, apparently, near to the posterior margin of the posterior testis ( $\mathrm{Zdz}-$ itowiecki, 1999).

The other members of Group C differ from M. vitellocopiosa in the same features as they do M. mutovillina and M. flexuomeatus.

\section{Macvicaria dextrocaula n. sp.}

Type-host: Notolabrus parilus (Richardson) (Labridae).

Other host: Notolabrus fucicola (Richardson) (Labridae).

Type-locality: Off Point Peron, Western Australia $32^{\circ} 18^{\prime} \mathrm{S}, 115^{\circ} 38^{\prime} \mathrm{E}$.

Other localities: Off North Mole, Western Australia 32 $03^{\circ}$ S, $115^{\circ} 43^{\prime} \mathrm{E}$.; Off American River, South Australia $35^{\circ} 48^{\prime} \mathrm{S}, 137^{\circ} 46^{\prime} \mathrm{E}$.

Site: Intestine.

Material studied: Ex Notolabrus parilus: 9 from off Point Peron Western Australia \& from off North Mole, December 1994; Ex Notolabrus fucicola: 1 from off American River, South Australia, December 1995.

Type-material: Holotype: QM G230415, paratypes: QM G230416-230422, BMNH 2008.7.5.40-43.

urn:lsid:zoobank.org:act:313FE42B-9AFC-4B01-A471-99DAFDE6153F

Description (Figs 24-29)

Based on 11 gravid, unflattened dorso-ventrally and laterally mounted specimens and 1 set of serial sagittal sections from Notolabrus parilus. Measurements of worm from Notolabrus fucicola are given in Table 3.

Measurements are of 5 gravid, unflattened, dorso-ventrally mounted worms. Body elongate-oval, sub-cylindrical, sharply inflected dorsally in area of ventral sucker in lateral 
view, with maximum width in region of ventral sucker, 936-1,455 $(1,202) \times 295-466$ (362); width to length ratio 1:3.2-3.6 (3.3). Oral sucker ventrally subterminal, sub-spherical, 129-169 (147) × 141-196 (164). Ventral sucker sub-spherical, close to mid-body, completely surrounded and almost completely enclosed by tegumental fold, 181-234 (212) × 197-276 (237), sucker-width ratio 1:1.4-1.5 (1.4) Forebody moderately long, 307-514 (408) long, 32-35 (34)\% body-length. Prepharynx indistinct, short, always entirely dorsal to oral sucker. Pharynx well developed, subglobular, usually partly dorsal to oral sucker, rarely entirely dorsal to oral sucker $(n=1) ; 49-65(55) \times 65-90(79)$; pharynx to oral sucker width ratio 1:1.9-2.2 (2.1). Oesophagus short, thick walled. Intestinal bifurcation 96-222 (163) anterior to ventral sucker. Caeca terminate blindly close to posterior extremity.

Testes 2 , entire, subspherical, tandem, contiguous to overlapping, close to posterior end of body, anterior 63-132 (98) × 112-194 (147); posterior 85-148 (115) $\times 112$ -

Table 3. Measurements (in $\mu \mathrm{m}$ ) of Macvicaria dextrocaula $\mathrm{n}$. sp. $(\mathrm{n}=1)$ from Notolabrus fucicola, Off American River, South Australia

\begin{tabular}{l|c}
\hline Total length & 1,168 \\
\hline Maximum width & 326 \\
Length/width & 3.6 \\
Oral sucker length & 140 \\
Oral sucker width (OSW) & 154 \\
Pharynx length & 51 \\
Pharynx width & 68 \\
OSW/pharynx width & 2.3 \\
Ovary length & 122 \\
Ovary width & 125 \\
Anterior testis length & 90 \\
Anterior testis width & 105 \\
Posterior testis length & 102 \\
Posterior testis width & 105 \\
Forebody-length (FBL) & 390 \\
FBL as \% of body-length & 33.4 \\
Ventral sucker length & 190 \\
Ventral sucker width (VSW) & 219 \\
VSW/OSW & 1.4 \\
Anterior extremity to genital pore (AEGP) & 231 \\
AEGP as \% body-length & 19.8 \\
Cirrus-sac length & 329 \\
Cirrus-sac width & 44 \\
Seminal vesicle length & 124 \\
Seminal vesicle width & 39 \\
Intestinal bifurcation to ventral sucker & 178 \\
Post-testicular region (PTR) & 201 \\
PTR as \% of body-length & 17.2 \\
Anterior extremity to vitellarium (AEV) & 145 \\
AEV as \% of body-length & 12.4 \\
Posterior extremity to vitellarium & 27 \\
Eggs & $23-37(31), \mathrm{n}=8$ \\
\hline & \\
\hline & $49-56(52)$ \\
\hline
\end{tabular}


196 (150). Post-testicular area short, 105-137 (127) long, 9.4-13(11)\% body-length. Cirrus-sac well developed, tubular, long, slender, extends from just posterior to intestinal bifurcation overlapping right caecum to point anterior to or posterior to ventral sucker aperture, 226-366 (297) × 34-60 (43). Internal seminal vesicle, slender, tubular, occupies posterior half of cirrus-sac, posterior portion surrounded by prostatic cells. Pars prostatica small, inconspicuous, surrounded by few gland cells. Ejaculatory duct relatively long, with few prostatic cells in rows along its length. Genital pore dextrally sub-median, caecal to extracaecal, just posterior to intestinal bifurcation, surrounded by gland cells, 209-290 (240) from anterior end, $17-24$ (20)\% body-length.

Ovary pretesticular, entire, subspherical, contiguously overlaps anterior testis, 90$139(104) \times 103-152$ (127). Mehlis' gland distinct antero-dorsal to ovary. Canalicular seminal receptacle saccular, antero-dorsal to ovary. Uterus coils between anterior testis and posterior margin of ventral sucker, sometimes overlapping caeca; terminal portion usually crammed with eggs. Metraterm distinct, surrounded by gland cells. Eggs oval, operculate, 39-56 (48) × 22-34 (28). Vitelline follicles extend from 130-185 (162) from anterior extremity, 11-18 (14)\% of body-length, to 8-24 (15.4) from posterior
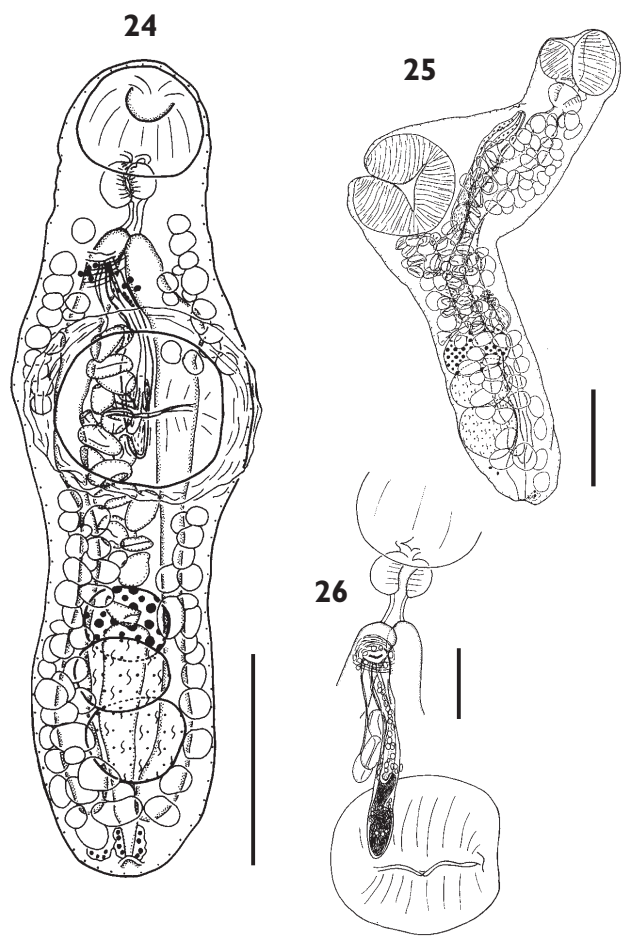

Figs 24-26. Macvicaria dextrocaula $\mathrm{n}$. sp. ex Notolabrus parilus. 24. Whole-mount ventral view. 25. Whole-mount lateral view. 26. Terminal genitalia. Scale bars: 24, 25, $250 \mu \mathrm{m} ; 26,100 \mu \mathrm{m}$.
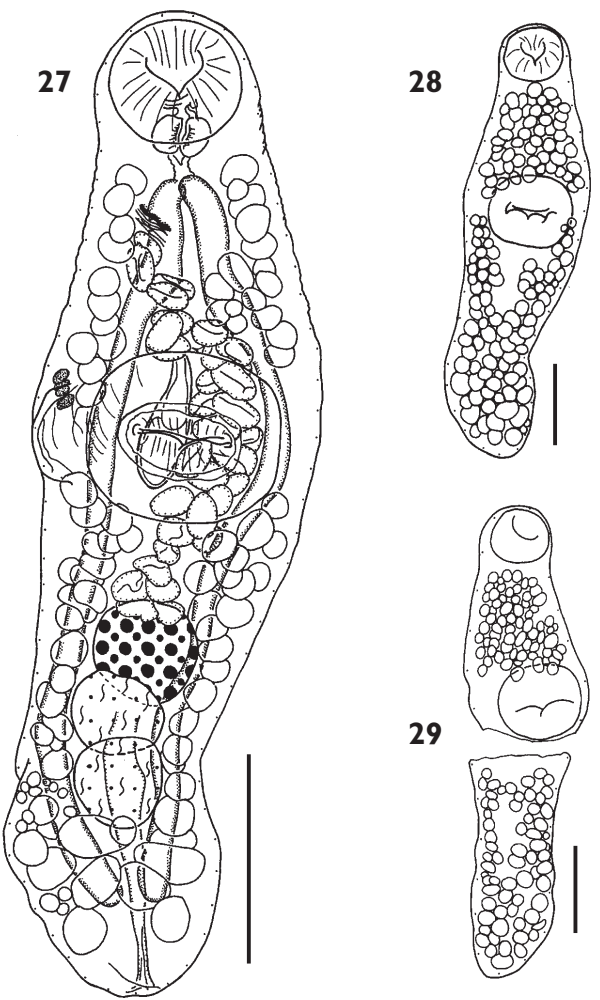

Figs 27-29. Macvicaria dextrocaula n. sp. ex Notolabrus fucicola and $N$. parilus. 27. Whole-mount ventral view. 28. Dorsal distribution of vitelline follicles. 29. Dorsal distribution of vitelline follicles (ex N. parilus). Scale bars: 27, 28, 29, $250 \mu \mathrm{m}$. 
extremity; follicles in two separate fields ventrally, confluent dorsally in forebody with interruption in ventral sucker area; fields lie lateral, ventral and dorsal to caeca with anterior limit usually anterior to posterior margin of pharynx, sometimes level with posterior margin $(n=2)$ or up to anterior margin of pharynx $(n=1)$.

Excretory pore usually ventrally subterminal, occasionally dorsally subterminal $(\mathrm{n}=1)$. Excretory vesicle I-shaped, posterior end narrow, surrounded by gland cells, wider anterior portion passes anteriorly to overlap posterior third of ovary dorsally.

Etymology: The specific name dextrocaula (L. dextra, right; L. caula, opening) refers to the worm's dextrally located genital pore.

Comments: One of the characteristics of Macvicaria species is their sinistral, ventrolateral, caecal or extra-caecal genital pore (Bartoli, Bray \& Gibson 1989). Since M. dextrocaula does not have a sinistral genital pore, like other members of the genus, the definition of Macvicaria is amended with respect to the position of the genital pore, to receive the new species as follows: genital pore sinistral or dextral, ventro-lateral, caecal or extra-caecal.

The specimens from Notolabrus fucicola are very similar to those from $N$. parilus except in the length of the post-testicular space, which is greater in the single worm from $N$. fucicola, $17.2 \%$ of body-length versus a maximum of $13.2 \%$ of body-length in the specimens from $N$. parilus. The specimen from $N$. fucicola also had slightly larger eggs than the worms from $N$. parilus. We interpret these slight differences either as induced by fixation or normal intraspecific variation.

Macvicaria dextrocaula can be accommodated in Group D as defined above. The new species can further be distinguished from the other species, apart from $M$. georgiana, by the distribution of the vitelline follicles which always reach further anteriorly, to the level of the pharynx, usually close to its anterior margin and from all other species by its strong dorsal inflection. Macvicaria dextrocaula differs from M. heronensis, M. issaitschikowi and M. georgiana by its smaller eggs.

Macvicaria heronensis Bray \& Cribb, 1989

Host: Trachinotus coppingeri (Gunther) (Carangidae).

Locality: Off Point Lookout, Stradbroke Island, Queensland. 27²6'S, 15332'E.

Site: Intestine.

Material studied: 1 from off Point Lookout, Stradbroke Island, Queensland.

Voucher specimen: QM G230423.

Description (Figs 30-32)

Based on 1 gravid unflattened whole-mount specimen. Measurements are of the single gravid, unflattened whole-mount.

Body fusiform, pointed at anterior and posterior ends, maximum width in region of ventral sucker; $1,101 \times 243$; width to length ratio $1: 4.5$. Oral sucker ventrally subterminal, sub-spherical, $78 \times 88$. Ventral sucker larger than oral sucker, transversely oval, protuberant, surrounded by tegumental fold, in posterior part of anterior half of body; $136 \times 169$, sucker-width ratio 1:9. Forebody moderately long, 389 long, 35.3\% 
body-length. Prepharynx distinct, short, almost entirely dorsal to oral sucker. Pharynx well developed, subglobular, $45 \times 58$; pharynx to oral sucker width ratio 1:1.5. Oesophagus distinct, moderately long. Intestinal bifurcation in anterior half of forebody, 156 anterior to ventral sucker. Caeca reach close to posterior extremity, terminate blindly. Excretory pore terminal. Excretory vesicle I-shaped, extends anteriorly to overlap posterior margin of ovary.

Testes 2, entire, sub-spherical, tandem, contiguous, in posterior third of body; anterior $58 \times 71$; posterior $97 \times 65$. Post-testicular area 207 long, $18.8 \%$ body-length. Cirrus-sac long, narrow, claviform, sigmoid anteriorly, thick walled, $266 \times 39$; extends from point just posterior to posterior margin of pharynx to overlap anterior margin of ventral sucker dorsally. Internal seminal vesicle tubular, long, narrow, loops anteriorly, occupies more than half of cirrus-sac. Pars prostatica distinct, small, surrounded by gland cells. Ejaculatory duct long, narrow, thick walled. Genital atrium small. Genital pore antero-sinistral to intestinal bifurcation, situated just posterior to posterior mar-

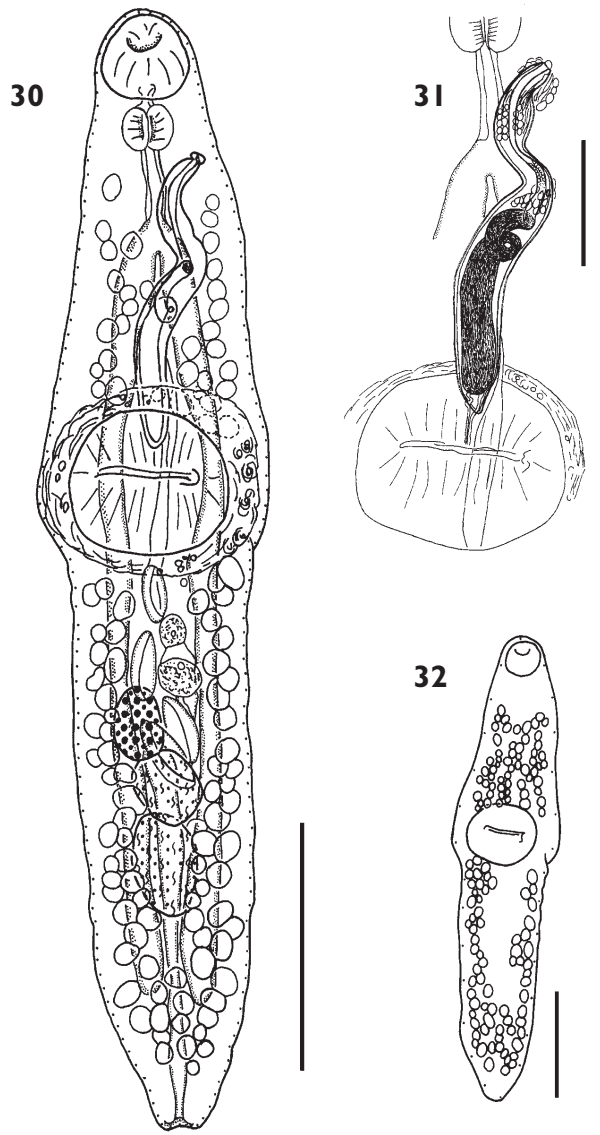

Figs 30-32. Macvicaria heronensis Bray \& Cribb, 1989 ex Trachinotus coppingeri. 30. Whole-mount ventral view. 31. Terminal genitalia. 32. Dorsal distribution of vitelline follicles. Scale bars: 30, 32, 250 $\mu \mathrm{m} ; 31,100 \mu \mathrm{m}$. 
gin of pharynx, closer to lateral margin of body than median line, 136 from anterior end, $12.4 \%$ of body-length.

Ovary pretesticular, entire, subspherical, contiguously antero-dextral to anterior testis, $65 \times 55$. Mehlis' gland indistinct. Canalicular seminal receptacle large, saccate, dorsal to ovary. Laurer's canal present. Uterus coils between anterior testis and posterior margin of ventral sucker, passes dorsally to cirrus-sac. Eggs large, oval, operculate, 68$84(76) \times 29-32(31)$. Metraterm dorsal to ejaculatory duct. Vitelline follicles extend from 156 from anterior extremity, 14.2\% body-length, to 39 from posterior extremity; follicles confluent dorsally in forebody and dorsally and ventrally in post-testicular area, in 2 separate fields ventrally in forebody; dorsal, ventral and lateral fields interrupted in ventral sucker area; fields lie lateral, ventral and dorsal to caeca; anterior extent level with genital pore.

Comments: Bray \& Cribb (1989) described Macvicaria heronensis from the lethrinids Lethrinus chrysostomus and Gymnocranius audleyi [= bitorquatus] from off Heron Island. Barker et al. (1994) subsequently recorded it from the pomacentrid Parma polylepis. This is the third report, and for the first time, from a carangid in temperate waters. The worm in this study compares more or less favourably with the one figured as 9B in Bray \& Cribb (1989), except that in our specimen the uterus extends posteriorly to overlap the anterior margin of the anterior testis, whereas in Bray \& Cribb's specimens, the uterus reaches only to the anterior margin of the anterior testis and they mentioned that in three of their specimens, the uterus overlapped the anterior testis only slightly. The forebody in our worm is also slightly longer than in Bray and Cribb's worms, $35 \%$ versus $31-32 \%$ of the length of the body. These differences may simply extend the variation of $M$. heronensis, or may link it to $M$. issaitschikovi, whose uterus has been illustrated and described by Layman (1930), Yamaguti (1938) and Manter \& Van Cleave (1951) as extending to the posterior edge of the anterior testis. Further comments on points of comparison between our worm and the worms described by Bray \& Cribb (1989) should await examination of more specimens from temperate waters to determine whether or not more than one species is involved.

\section{Macvicaria adomeae n. sp.}

Type-host: Sillaginodes punctatus (Cuvier) (Sillaginidae).

Type-locality: Off American River, South Australia 3548'S, $137^{\circ} 46^{\prime} \mathrm{E}$.

Site: Gut.

Material studied: 9 Off American River, South Australia, December 1995.

Type-material: Holotype: QM G230424, paratypes: QM G230425-230427, BMNH 2008.7.5.44-45.

urn:lsid:zoobank.org:act:EBF2012C-678A-4BEA-8C97-5DE132F6AB60

Description (Figs 33-36)

Based on 8 unflattened, whole-mount specimens and 1 set of serial sagittal sections and measurements of 5 gravid unflattened whole-mount worms. 
Body elongate, spindle shaped, maximum width in region of ventral sucker, $1,140-1,578(1,315) \times 302-363(331)$; width to length ratio 1:3.4-4.3 (4.0). Oral sucker globular, opening ventrally subterminal, 88-104 (95) × 98-110 (113). Ventral sucker transversely oval, in anterior third of body, 158-179 (167) $\times 181-213$ (101); sucker width ratio 1:1.8-1.9 (1.9). Forebody 358-456 (396) long, 27-35 (30)\% of body-length. Prepharynx short, dorsal to oral sucker. Pharynx subglobular, 48-59 (55) $\times$ 60-70 (65); pharynx to oral sucker width ratio 1:1.5-1.6 (1.6). Oesophagus distinct, short. Intestinal bifurcation in forebody, 107-166 (134) anterior to ventral sucker. Caeca terminate blindly close to posterior extremity. Excretory pore ventrally subterminal.

Testes 2 , oval, entire, contiguous to slightly separated, tandem, in posterior half of body, anterior 115-161 (136) × 121-145 (131), posterior 147-193 (166) $\times 121-159$ (143). Post-testicular area 213-387 (300) long, 19-27 (23)\% of body-length. Cirrussac elongate, clavate, thick walled, extends from point just posterior to posterior margin of pharynx, overlaps ventral sucker dorsally to its aperture $(n=2)$, sometimes to level of $(n=2)$ or posterior to posterior margin of ventral sucker $(n=2), 303-412(371)$ $\times$ 61-92 (74). Internal seminal vesicle tubular, sinuous, broadest at posterior end, fills broad posterior portion of cirrus-sac, surrounded by gland cells anteriorly. Pars prostatica distinct, thick walled, surrounded by gland cells. Ejaculatory duct long, thick walled. Genital atrium small. Genital pore antero-sinistral to intestinal bifurcation,
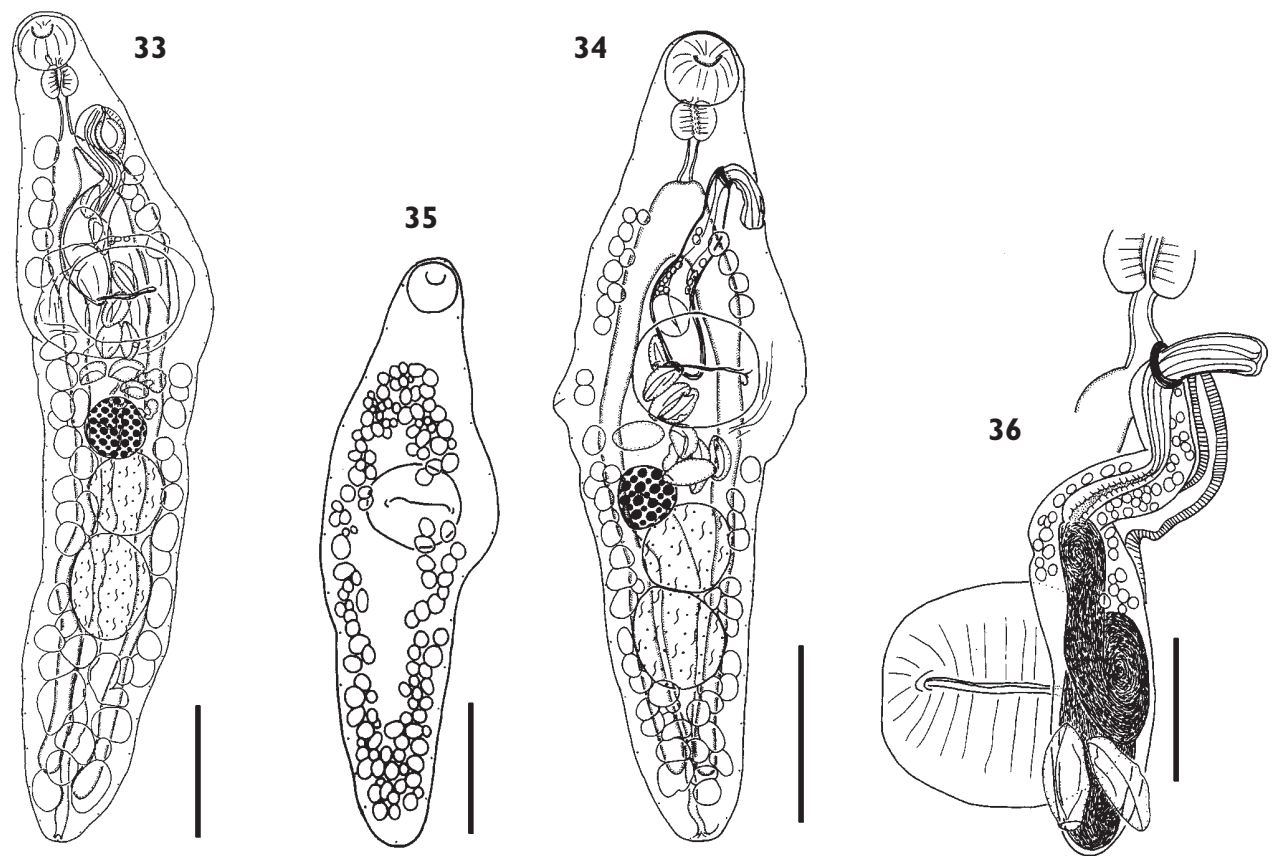

Figs 33-36. Macvicaria adomeae n. sp. ex Sillaginodes punctatus. 33. Whole-mount ventral view. 34. Whole-mount ventral view. 35. Dorsal distribution of vitelline follicles. 36. Terminal genitalia. Scale bars: $33,34,35,250 \mu \mathrm{m} ; 36,100 \mu \mathrm{m}$. 
midway between lateral margin and oesophagus, usually with cirrus protruding, $(n=4)$, 189-209 (199) from anterior end, 13-18 (15)\% of body-length.

Ovary entire, spherical, contiguously anterior to or antero-dextral to anterior testis, 73-117 (89) $\times$ 78-115 (95). Mehlis' gland indistinct, usually anterior to ovary, occasionally sinistral $(n=1)$ to ovary. Canalicular seminal receptacle saccular, usually dorsal $(n=4)$, sometimes antero-dextral $(n=1)$, or sinistral to ovary, overlapping left side of ovary and anterior portion of anterior testis $(n=1)$. Laurer's canal present, opens dorso-sinistrally to ovary. Uterus coils intercaecally between anterior testis and ventral sucker, sometimes overlaps caeca ventrally, and ovary and testis dorsally, then passes to genital pore without coiling. Metraterm distinct, thick walled, overlaps left caecum. Eggs few, large, operculate, oval, 61-78 (70) × 28-50 (37). Vitelline follicles extend from 182-202 (194) from anterior extremity, 19-27 (23)\% of body-length, to 11-38 (26) from posterior extremity; lateral fields may be continuous $(n=3)$ or interrupted in ventral sucker area $(n=3)$, ventral fields separate in forebody, and posteriorly to posterior margin of posterior testis, confluent or almost in post-testicular area; dorsal field confluent in forebody and post-testicular area always with continuous medial and sometimes bilateral or unilateral interruption in ventral sucker, uterine and gonad areas; follicles lie lateral, ventral and dorsal to caeca; anterior limit sometimes level with posterior end of oesophagus $(n=3)$ or more anteriorly to point roughly level with mid-way between anterior and posterior ends of oesophagus $(n=3)$.

Excretory vesicle I-shaped, with narrow posterior end surrounded by few gland cells, passes anteriorly to point dorsal to posterior third of ovary.

Etymology: This species is named for the mother of the first author.

Comments: Macvicaria adomeae n. sp. can be accommodated in Group D as outlined above and can be distinguished from other species as follows:

M. antarctica has a smaller pharynx, a shorter forebody at $26 \%$ of the body-length, a smaller post-testicular area and distinctly smaller eggs 42-51 × 20-28.

M. georgiana has vitelline fields reaching to the pharynx, a saccular internal seminal vesicle, a shorter forebody (according to the illustrations in Zdzitowiecki, 1997) and small knobs on the anopercular pole of the eggs.

M. issaitschikowi has a shorter forebody at $27 \%$ of the body-length, a slightly shorter post-testicular area of $19 \%$ of the body-length, a smaller pharynx, a larger ventral sucker, with a sucker width ratio of 1:2.61 versus 1:1.8-1.9 (1.9), smaller eggs 57-63 x $38-40$, and its caeca terminate at about the level of the posterior margin of the posterior testis (Yamaguti, 1938) whereas they terminate well beyond the posterior margin of the posterior testis in $M$. adomeae.

M. muraenolepidis has a saccular internal seminal vesicle and smaller eggs (36-50 x 21-32) with small anopercular knobs.

$M$. heronensis can be distinguished by its slightly longer forebody at $35 \%$ of the body-length, a shorter post-testicular area at $19 \%$ of the body-length, longer and narrower eggs at $68-84 \times 29-32(76 \times 31)$, the posterior extent of the uterus, the gonads which are situated more posteriorly and a genital pore closer to the anterior end. 
Macvicaria kingscotensis $\mathrm{n}$. sp.

Type-host: Neoodax balteatus Valenciennes (Odacidae).

Other host: Haletta semifasciata (Valenciennes) (Odacidae).

Type-locality: Off Kingscote, South Australia, 3540'S, $137^{\circ} 39^{\prime} \mathrm{E}$.

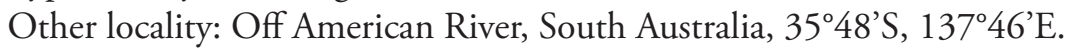

Site: Intestine.

Material Examined: Ex Neoodax balteatus: 6 from off Kingscote; Ex Haletta semifasciata: 2 from off American River, S.A, December 1995.

Type-material: Holotype: QM G230428, paratypes: QM G230429-230432, BMNH 2008.7.5.46-48.

urn:lsid:zoobank.org:act:014A738F-826F-4F1A-B425-FEBFF266A8B0

Description (Figs 37-42)

Based on 5 gravid, unflattened whole-mount specimens and 1 set of serial sagittal sections from Neoodax balteatus. Measurements of worms from Haletta semifasciata are given in Table 4. Measurements are of the 5 gravid, unflattened, whole-mounts from Neoodax balteatus.

Body elongate, fusiform, maximum width in area of ventral sucker or gonads, $1,067-1,447(1,248) \times 253-332(282)$; width to length ratio 1:3.9-5.0 (4.4). Oral sucker ventrally subterminal, subglobular, 87-113 (97) × 101-118 (107). Ventral sucker larger than oral sucker, pre-equatorial, spherical to sub-spherical, 144-165 (155) $\times$ 155-188 (173); sucker width ratio 1:1.4-1.8 (1.6). Forebody contains numerous gland cells, 373-508 (425) long, 31-36 (34)\% body-length. Prepharynx distinct, usually antero-dorsal to posterior margin of oral sucker, occasionally partially postero-dorsal. Pharynx large, sub-spherical, 53-65 (59) $\times$ 71-87 (77); pharynx to oral sucker width ratio 1:1.3-1.5 (1.4). Oesophagus distinct, well developed. Intestinal bifurcation in forebody, 114-180 (144) anterior to ventral sucker. Caeca terminate blindly close to posterior extremity.

Testes 2, entire, usually sub-spherical, occasionally irregular $(n=1)$, contiguous, flattened at contiguity, tandem, in posterior half of body; anterior 120-165 (137) $\times$ 127-153 (144); posterior 159-203 (183) × 125-151 (134). Post-testicular space relatively short, 166-282 (217) long, 16-19 (17)\% of body-length. Cirrus-sac clavate, long, thick walled, extends from point antero-sinistral to intestinal bifurcation to point level with or just posterior to ventral sucker aperture, 275-387 (322) × 43-51 (47). Internal seminal vesicle long, tubular; sinuous, looped and narrow at anterior end, broader at posterior end; occupies posterior portion of cirrus-sac. Pars prostatica distinct, narrow, surrounded by gland cells. Ejaculatory duct relatively long, thick walled, surrounded by gland cells. Genital atrium small. Genital pore extra-caecal, antero-sinistral to intestinal bifurcation, 168-222 (194) from anterior end, 15-16 (15.6)\% of body-length.

Ovary usually entire, occasionally indistinctly lobed $(n=1)$, sub-spherical, contiguously antero-dextral to anterior testis, flattened at contiguity, 98-108 (104) $\times$ 66-104 (84). Mehlis' gland distinct, dorso-sinistral to ovary. Canalicular seminal re- 
ceptacle large, saccular, dorsal to ovary, overlapping anterior margin of anterior testis. Laurer's canal present. Uterus usually coils between point ventral and posterior to, or ventral to anterior margin of anterior testis and posterior margin of ventral sucker overlapping caeca and lateral and anterior margins of ovary, sometimes overlapping posterior margin of ventral sucker to its aperture $(n=2)$, leads to genital pore without coiling. Metraterm distinct, surrounded by gland cells. Eggs large, oval, operculate, tanned, 59-83 (72) × 29-47 (35). Vitelline follicles extend from 159-216 (191) from anterior extremity, 13-20 (15)\% of body-length, to 31-76 (46) from posterior extremity, with bilateral interruption in ventral sucker area; fields confluent dorsally and ventrally in post-testicular area and in forebody dorsally, separate ventrally in forebody; follicles lie lateral, ventral and dorsal to caeca; anterior limit may be just anterior to posterior end of oesophagus or posterior margin of pharynx or occasionally anterior to anterior margin of pharynx $(n=1)$.

Table 4. Measurements (in $\mu \mathrm{m}$ ) of Macvicaria kingscotensis $\mathrm{n}$. sp. from Haletta subfasciatus ( $\mathrm{n}=2)$.

\begin{tabular}{l|c|c|c}
\hline Total length & Min. & Max. & Mean \\
\cline { 2 - 4 } & 844 & 971 & 908 \\
\hline Maximum width & 258 & 283 & 271 \\
Length/width & 3.3 & 3.4 & 3.4 \\
Oral sucker length & 80 & 80 & 80 \\
Oral sucker width (OSW) & 92 & 95 & 94 \\
Pharynx length & 48 & 53 & 51 \\
Pharynx width & 62 & 65 & 64 \\
OSW/pharynx width & 1.4 & 1.5 & 1.5 \\
Ovary length & 80 & 81 & 80.5 \\
Ovary width & 61 & 68 & 65 \\
Anterior testis length & 104 & 107 & 106 \\
Anterior testis width & 109 & 109 & 109 \\
Posterior testis length & 127 & 137 & 132 \\
Posterior testis width & 117 & 119 & 118 \\
Forebody-length (FBL) & 301 & 301 & 301 \\
FBL as \% of body-length & 31.0 & 35.7 & 33.3 \\
Ventral sucker length & 141 & 144 & 143 \\
Ventral sucker width (VSW) & 127 & 148 & 138 \\
VSW/OSW & 1.4 & 1.6 & 1.5 \\
Anterior extremity to genital pore (AEGP) & 152 & 153 & 153 \\
AEGP as \% body-length & 15.7 & 18.1 & 16.9 \\
Cirrus-sac length & 237 & 237 & 237 \\
Cirrus-sac width & 47 & 47 & 47 \\
Intestinal bifurcation to ventral sucker & 93 & 93 & 93 \\
Post-testicular region (PTR) & 153 & 156 & 155 \\
PTR as \% of body-length & 15.8 & 18.5 & 17.1 \\
Anterior extremity to vitellarium (AEV) & 150 & 163 & 157 \\
AEV as \% of body-length & 16.8 & 17.8 & 17.3 \\
Posterior extremity to vitellarium & 41 & 43 & 42 \\
Eggs & $71-77$ & $(76)$ & $\times 32-37(34), \mathrm{n}=5$ \\
\hline
\end{tabular}


Excretory pore terminal. Excretory vesicle I-shaped; short terminal portion narrow, surrounded by few gland cells; anterior portion widens and passes anteriorly to point just posterior to anterior margin of anterior testis.

Etymology: This species is named after its type locality, Off Kingscote in South Australia.

Comments: The worms from Neoodax balteatus are metrically very similar to those from Haletta semifasciata, but they are longer and more slender, having non-overlapping width to length ratios of 1: 3.9-5.0 (4.4) versus 3.3-3.4 (3.4), respectively. This difference could have been induced by fixation or the host in either case.

Macvicaria kingscotensis $\mathrm{n}$. sp. has the morphological features of the worms in Group D, as outlined above. It can be distinguished from the other worms in Group D as follows:

M. antarctica has a smaller pharynx, its pharynx to oral sucker width ratio being 1:1.8-2.2 (1.92), a shorter forebody measuring $25 \%$ of the body-length, smaller eggs measuring $42-51 \times 20-28$ and a genital pore which is slightly more anteriorly situated.
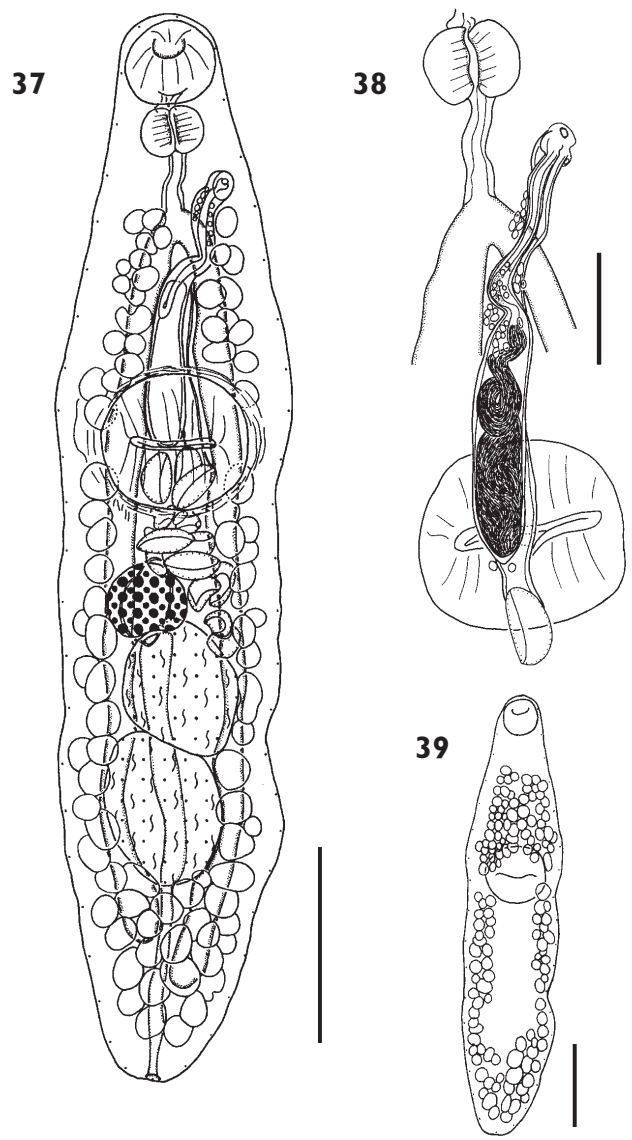

Figs 37-39. Macvicaria kingscotensis $\mathrm{n}$. sp. ex Neoodax balteatus. 37. Whole-mount ventral view. 38. Terminal genitalia. 39. Dorsal distribution of vitelline follicles. Scale bars: 37, 39, $250 \mu \mathrm{m} ; 38,100 \mu \mathrm{m}$. 

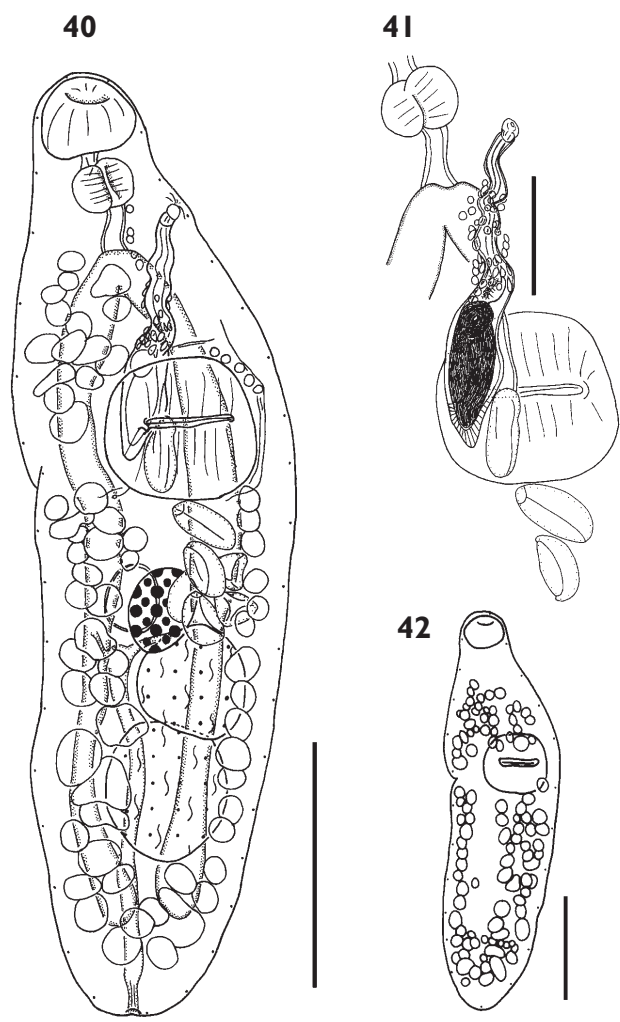

Figs 40-42. Macvicaria kingscotensis $\mathrm{n}$. sp. ex Haletta semifasciata. 40. Whole-mount ventral view. 41. Terminal genitalia. 42. Dorsal distribution of vitelline follicles. Scale bars: 40, 42, $250 \mu \mathrm{m} ; 41,100 \mu \mathrm{m}$.

M. adomeae can be distinguished by its larger ventral sucker which is reflected in a sucker width ratio of 1:1.8-1.9 (1.9) and by its fusiform body-shape.

M. georgiana has vitelline fields reaching the pharynx, a saccular internal seminal vesicle, a shorter forebody (according to the illustrations in Zdzitowiecki, 1997) and small knobs on the anopercular pole of the eggs.

$M$. heronensis has a larger ventral sucker, with a sucker width ratio of 1:1.9, slightly longer eggs at $68-84 \times 29-32(76 \times 31)$, a genital pore situated slightly more anteriorly (12.4\% of the body-length from the anterior extremity) and the ovary is more distant from the ventral sucker.

M. muraenolepidis has a saccular internal seminal vesicle and small eggs $(36-50 \times$ 21-32) with small anopercular knobs.

\section{Discussion}

All of the hosts reported in this paper are endemic to Australian or Australian and New Zealand waters, apart from Apogon fasciata, the type-host of $M$. shotteri, which 
is widespread in the Indo-West Pacific. The level of marine fish endemicity is high in the waters off southern Australia (about $85 \%$ at the species level according to Wilson $\&$ Allen, 1987), so it would not be surprising if the parasites are similarly endemic. Manter (1967) estimated 95\% species endemicity in southern Australia marine fish digeneans and Bray et al. (1999) estimated that species of the digenean family Lepocreadiidae Odhner, 1905 showed about 83\% endemicity in southern Australia, and if those also found in New Zealand are taken into account the level of endemicity rises to about $92 \%$. Our knowledge of the large opecoelid fauna of Australia is rudimentary, but the results presented here indicate similar levels of endemicity in the genus Macvicaria, at least. Of the eleven species reported so far from Australian waters only one, M. macassarensis, has been reported from elsewhere (off Sulawesi). In this paper we record $M$. heronensis in Australian temperate waters for the first time, but its newly reported host, Trachinotus coppingeri is restricted to eastern Australia, including the Great Barrier Reef, the site of the previous findings of this parasite. The host of M. dampieri, Pseudorhombus jenynsi, is the only non-perciform host reported for Macvicaria in Australian waters: it is said to inhabit 'most coasts of Australia' (Froese \& Pauly, 2008). Notolabrus fucicola, one of the hosts of $M$. dextrocaula n. sp., is found off New Zealand in addition to southern Australia and all other hosts reported for new species in this paper are restricted to southern Australia, including the southern parts of Western Australia, the south-eastern states and Tasmania. Thus of the eleven species so far reported from Australian waters, ten (91\%) are likely to be endemic.

\section{Acknowledgements}

We thank the Australian and Nigerian governments, Ahmadu Bello University, Zaria, Nigeria and the Australian Biological Resources Study for financial support. We also thank Drs Alistair Dove and Sylvie Pichelin, and Trudy Wright and Scott Burge for assistance in the field. Special thanks are due to Dr Richard Pyle (Bishop Museum, Honolulu) for registration of names, authors and current article in ZooBank.

\section{References}

Al-Yamani FY, Nahhas FM (1981) Digenetic trematodes of marine fishes from the Kuwaiti coast of the Arabian Gulf. Kuwait Bulletin of Marine Science 3: 1-22.

Barker SC, Cribb TH, Bray RA, Adlard RD (1994) Host-parasite associations on a coral reef: pomacentrid fishes and digenean trematodes. International Journal for Parasitology 24: 643-647.

Bartoli P, Bray RA, Gibson DI (1989) The Opecoelidae (Digenea) of sparid fishes of the Western Mediterranean. III. Macvicaria Gibson and Bray, 1982. Systematic Parasitology 13: 167-192. 
Bartoli P, Gibson DI, Bray RA (1988) The Opecoelidae (Digenea) of sparid fishes of the western Mediterranean. I. Pachycreadium Manter, 1954. Systematic Parasitology 12: 231-239. Bartoli P, Gibson DI, Bray RA (1993) The Opecoelidae (Digenea) of sparid fishes of the western Mediterranean. VI. A rediscription of Macvicaria mormyri (Stossich, 1885) n. comb. and a key to the opecoelids from western Mediterranean sparids. Systematic Parasitology 26: 59-67.

Bray RA (1985) Macvicaria taksengi n. sp. (Digenea: Opecoelidae) in marine teleosts from Pinang, Malaysia. Systematic Parasitology 7: 75-80.

Bray RA (1990) Two new opecoelids (Digenea) in the flatfish Pseudorhombus jenynsi (Bleeker) from Shark Bay, Western Australia. Systematic Parasitology 15: 33-40.

Bray RA, Cribb TH (1989) Digeneans of the family Opecoelidae Ozaki, 1925 from the Southern Great Barrier Reef, including a new genus and three new species. Journal of Natural History, 23: 429-473.

Bray RA, Cribb TH, Pichelin SP (1999) Two new species of lepidapedines (Digenea, Lepocreadiidae) from the King George whiting Sillaginodes punctata (Perciformes, Sillaginidae) from off Kangaroo Island, South Australia. Acta Parasitologica, 44: 108-114.

Cribb TH (2005) Family Opecoelidae Ozaki, 1925. In: Jones A, Bray RA, Gibson DI (Eds) Keys to the Trematoda. Volume 2. Wallingford: CABI Publishing and the Natural History Museum, 443-531.

Fischthal JH, Kuntz RE (1964) Digenetic trematodes of fishes from Palawan Island, Philippines.

Part II. Five Opecoelidae, including three new species. Proceedings of the Helminthological Society of Washington: 40-46.

Fischthal JH, Thomas JD (1970) Digenetic trematodes of marine fishes from Ghana: Family Opecoelidae. Proceedings of the Helminthological Society of Washington 37: 129-141.

Fischthal JH, Thomas JD (1972) Digenetic trematodes of marine fishes from Senegal. Bulletin l'Institut Fondamental Francais d'Afrique Noire. Ser A. Sciences Naturelles, 34: 292-322.

Froese R, Pauly D (2008) FishBase: World Wide Web electronic publication. Available on http://www.fishbase.org.

Gibson DI (1976) Monogenea and Digenea from fishes. Discovery Reports 36: 244-253.

Gibson DI, Bray RA (1982) A study and reorganization of Plagioporus Stafford, 1904 (Digenea:

Opecoelidae) and related genera, with special reference to forms from European Atlantic waters. Journal of Natural History 16: 529-559.

Gupta PC, Gupta VC (1988) On three opecoelid trematodes (Digenea) from marine fishes, Bay of Bengal, India. Proceedings of Parasitology, 6: 59-68.

Gupta PC, Singh RB (1985) Four new digenetic trematodes from marine fishes off Puri coast, Bay of Bengal. Indian Journal of Parasitology 9: 25-34.

Hafeezullah M (1971) Opecoelid trematodes of marine fishes of India. Parasitology 62: 321-329. Hassanine RME-S, Gibson DI (2005) Trematodes from Red Sea fishes: Neohypocreadium aegyptense n. sp. (Lepocreadiidae), Fairfaxia cribbi n. sp. and Macvicaria chrysophrys (Nagaty \& Abdel-Aal, 1969) (Opecoelidae). Systematic Parasitology 62: 199-207.

Layman EM (1930) Parasitic worms from fishes of Peter the Great Bay. Izvestiya Tikhookeanoskoi

Nauchno-Promyslovoi Ostantsii 3: 1-120. [In Russian and German].

Linton E (1910) Helminth fauna of the Dry Tortugas. II. Trematodes. Papers from the Tortugas Laboratory of the Carnegie Institute of Washington 4: 11-98. 
Madhavi R (1975) Digenetic trematodes from marine fishes of Waltair Coast, Bay of Bengal. Family Opecoelidae. Rivista di Parassitologia 36: 153-164.

Manter HW (1940) Digenetic trematodes of fishes from the Galapagos Islands and the neighbouring Pacific. Allan Hancock Pacific Expeditions 2: 364-473.

Manter HW (1954) Some digenetic trematodes from fishes of New Zealand. Transactions of the Royal Society of New Zealand 82: 475-568.

Manter HW (1963) Studies on digenetic trematodes of fishes of Fiji. II. Families Lepocreadiidae, Opistholebetidae, and Opecoelidae. Journal of Parasitology 49: 99-113.

Manter HW (1967) Some aspects of the geographical distribution of parasites. Journal of Parasitology, 53: 1-9.

Manter HW, Van Cleave HJ (1951) Some digenetic trematodes, including eight new species, from marine fishes of La Jolla, California. Proceedings of the United States National Museum 101: 315-340.

Nagaty HF, Abdel Aal TM (1969) Trematodes of fishes from the Red Sea. Part 18. On two new and one known allocreadiid species. Journal of the Egyptian Veterinary Medical Association 29: 1-5.

Nicoll W (1910) On the Entozoa of fishes from the Firth of Clyde. Parasitology 3: 322-359.

Reimer LW (1987) Opecoelidae (Trematoda) von Meeresfischen vor Moçambique. Angewandte Parasitologie 28: 143-158.

Shalaby IMI, Hassanine RME-S (1997) Cryptacetabulum aegyptensis n. gen. n. sp. (Trematoda, Digenea: Opistholebetidae) from a Red Sea fish; as described by light and scanning electron microscopy. Journal of the Egyptian German Society of Zoology 24: 247-259.

Shen J-w, Qiu Z-z (1995) Studies on the trematodes of fishes from the Yellow Sea and the Bo Hai Sea. Beijing; Science Press, 207 pp. (In Chinese).

Wang Y-Y, Wang P-Q, Zhang W-H (1992) Opecoelid trematodes of marine fishes from Fujian Province. Wuyi Science Journal 9: 67-89 (In Chinese).

Wilson BR, Allen GR (1987) Major components and distribution of marine fauna. In: Dyne GR, Walton DW (Eds) Fauna of Australia. General Articles. Vol. 1A. Canberra: Australian Government Publishing Service, 43-68.

Yamaguti S (1937) Studies on the Helminth fauna of Japan. Part 17. Trematodes from a marine fish, Brachiostegus japonicus (Houttuyn). Place of publication not given; Satyû Yamaguti, 15 pp.

Yamaguti S (1938) Studies on the helminth fauna of Japan Part 21. Trematodes of fishes, IV. Kyoto; Satyû Yamaguti, 139 pp.

Yamaguti S (1952) Parasitic worms mainly from Celebes. Part 1. New digenetic trematodes of fishes. Acta Medicinae Okayama 8: 146-198.

Yamaguti S (1971) Synopsis of digenetic trematodes of vertebrates. Tokyo; Keigaku, Vol. 1. 1074 pp. Vol. 2. 349 pp.

Zdzitowiecki K (1990) Antarctic representatives of the genus Macvicaria Gibson and Bray, 1982 (Digenea: Opecoelidae), with description of two new species. Systematic Parasitology 16: 169-179.

Zdzitowiecki K (1997) Antarctic Digenea parasites of fishes. Synopsis of the Antarctic Benthos 8: 1-156. 
Zdzitowiecki K (1999) Digeneans of the families Opecoelidae and Lepocreadiidae, parasites of Lepidonotothen macrophthalma from the North Scotia Ridge, and remarks on the discrimination of Neolepidapedon magnatestis and N. trematomi. Acta Parasitologica 44: 233-240.

Zdzitowiecki K, Cielecka D (1997) Digenea of fishes of the Weddell Sea. II. The genus Macvicaria (Opecoelidae). Acta Parasitologica 42: 77-83.

Zdzitowiecki K, Pisano E, Vacchi M (1992) Additional data to Antarctic representatives of the genus Macvicaria Gibson \& Bray, 1982 (Digenea, Opecoelidae), with a key to species occurring in the Antarctic. Acta Parasitologica 37: 131-134. 